\title{
Blunt-Body Entry Vehicle Aerothermodynamics: Transition and Turbulence on the CEV and MSL Configurations
}

\author{
Brian R. Hollis* \\ NASA Langley Research Center, Hampton, VA, 23681
}

\begin{abstract}
Recent, current, and planned NASA missions that employ blunt-body entry vehicles pose aerothermodyamic problems that challenge the state-of-the art of experimental and computational methods. The issues of boundary-layer transition and turbulent heating on the heat shield have become important in the designs of both the Mars Science Laboratory and Crew Exploration Vehicle. While considerable experience in these general areas exists, that experience is mainly derived from simple geometries; e.g. sharp-cones and flat-plates, or from lifting bodies such as the Space Shuttle Orbiter. For blunt-body vehicles, application of existing data, correlations, and comparisons is questionable because an all, or mostly, subsonic flow field is produced behind the bow shock, as compared to the supersonic (or even hypersonic) flow of other configurations. Because of the need for design and validation data for projects such as MSL and CEV, many new experimental studies have been conducted in the last decade to obtain detailed boundary-layer transition and turbulent heating data on this class of vehicle. In this paper, details of several of the test programs are reviewed. The laminar and turbulent data from these various test are shown to correlate in terms of edge-based Stanton and Reynolds number functions. Correlations are developed from the data for transition onset and turbulent heating augmentation as functions of momentum thickness Reynolds number. These correlation can be employed as engineeringlevel design and analysis tools.
\end{abstract}

\section{Nomenclature}

$=$ skin friction coefficient

$=$ vehicle diameter

$=$ adiabatic wall enthalpy

$=$ total free stream enthalpy

$=$ wall static enthalpy

$=$ wall static enthalpy at $300 \mathrm{~K}$

$=$ free stream Mach number

$=$ boundary-layer edge Mach number

$=$ free stream pressure

$=$ Prandtl number

$=$ heat transfer rate

$=$ hemispherical nose radius

$=$ free stream unit Reynolds Number $\rho_{\infty} U_{\infty} / \mu_{\infty}$

$=$ free stream unit Reynolds Number $\rho_{e} U_{e} / \mu_{e}$

$=$ boundary-layer momentum thickness Reynolds Number $\rho_{e} U_{e} \theta / \mu_{e}$

$=$ Stanton number based on free stream conditions $\dot{q}_{w} /\left[\rho_{\infty} U_{\infty}\left(H_{0}-H_{w}\right)\right]$

$=$ Stanton number based on boundary layer edge conditions $\dot{q}_{w} /\left[\rho_{e} U_{e}\left(H_{a w}-H_{w}\right)\right]$

$=$ free stream temperature

$=$ free stream velocity

$=$ boundary layer edge velocity

$=$ normalized distance along model centerline for MSL local coordinate system

$=$ normalized distance along model centerline for CEV local coordinate system

$=$ angle of attack

$\beta_{L}=$ factor in laminar heating correlation $\left[\left(\rho_{\infty} \mu_{\infty}\right) /\left(\rho_{e} \mu_{e}\right)\right]^{1 / 2}\left(\rho_{e} / \rho_{\infty}\right)^{1 / 4}$

\footnotetext{
* Aerospace Engineer, Aerothermodynamics Branch, Senior AIAA Member
} 


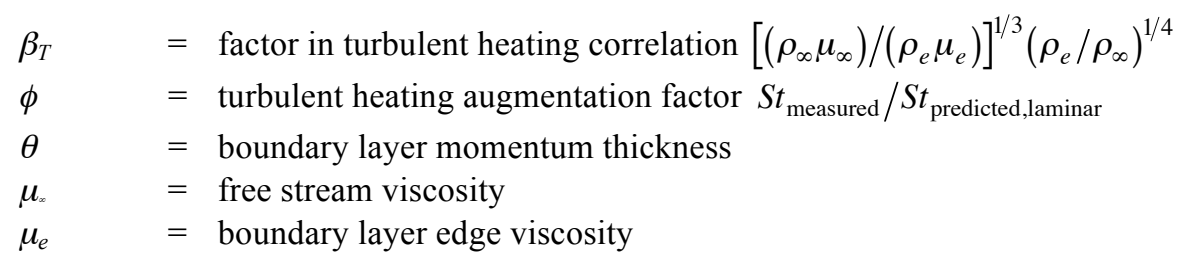

\section{Background}

Blunt body configurations are the most common geometries employed for entry into planetary atmospheres. Examples of manned blunt-body entry vehicles include the Mercury, Gemini, and Apollo capsules. Examples of unmanned flight test or interplanetary probe blunt-body entry vehicles are more numerous and include the Viking, Pioneer, FIRE II, ARD, OREX, Stardust, etc. An overview of major programs that includes vehicle and mission descriptions in which blunt body entry vehicles have been employed is given in Ref. 1.

Historically, turbulent flow at hypersonic speeds has generally been considered to be a design issue for moderate to high lift-to-drag ratio lifting body and winged vehicles, such as the Shuttle Orbiter, rather than for blunt body entry vehicles. These vehicles travel at high Reynolds numbers and their large size provides sufficient length over which turbulent flow can develop. In contrast, blunt-body re-entry vehicles generally are smaller and have high drag coefficients that cause rapid deceleration, which thus decreases the likelihood of producing turbulent flow.

However, the problem of turbulent heating has become important in recent blunt-body vehicle designs, notably the Mars Science Laboratory (MSL) and the Orion Crew Exploration Vehicle (CEV). Both these vehicles are, in comparison to past blunt-body vehicles, quite large: the MSL is $4.5 \mathrm{~m}$ in diameter and the CEV will be $\sim 5 \mathrm{~m}$ in diameter. Furthermore, both vehicles will experience atmospheric entry (at Mars and Earth, respectively) at high speeds ( $\sim 11 \mathrm{~km} / \mathrm{s}$ for CEV and $\sim 5 \mathrm{~km} / \mathrm{s}$ for MSL) and fly high angle-of-attack (for blunt bodies) lifting trajectories (11-deg to 16-deg range for MSL and 16-deg to 24-deg range for CEV). These factors all tend to promote transition to turbulent flow, and thus the conservative design philosophy applied in both projects is to assume turbulent flow throughout their trajectories.

This assumption of turbulent flow led to the requirement to conduct high-Reynolds number hypersonic aeroheating testing on each vehicle in order to obtain turbulent heat transfer data. These data are used in the evaluation of the CFD models employed in the design of each vehicle. Several examples of these experimental studies will be presented in which comparisons with CFD results have been performed.

\section{MSL and CEV Project Descriptions}

In this discussion of blunt-body transition and turbulence, ground test programs and supporting computational analyses will be presented for the Mars Science Laboratory and the Project Orion Crew Exploration Vehicle. Brief overviews of each vehicle and mission are presented below.

The Mars Science Laboratory (MSL) mission (Ref. 2), to be launched in 2011, will deliver the largest (>900 $\mathrm{kg}$ ) rover ever to Mars. The MSL vehicle (Figure 1) will fly a controlled, lifting trajectory ( $\alpha=16 \mathrm{deg}$ ) to deliver the payload to within $10 \mathrm{~km}$ of the target location. The entry vehicle is comprised of a $4.5 \mathrm{~m}$ diameter sphericallyblunted, 70-deg half-angle cone forebody heat shield that protects the aftbody payload from entry heating and provides a hypersonic lift-to-drag (L/D) ratio of 0.24 for aerodynamic control and maneuvering. The MSL vehicle will enter the Martian atmosphere at a velocity of $5.6 \mathrm{~km} / \mathrm{sec}$, which is greater than that of any other Mars probe except Mars Pathfinder. Because of the vehicle's large heat shield diameter and the high angle of attack and velocity of its entry trajectory, it is expected that the vehicle will experience boundary-layer transition to turbulent flow well before the peak heating point on the trajectory. Therefore the vehicle's Thermal Protection System (TPS) was designed (Refs. 3-4) with a conservative assumption of turbulent flow throughout the entire trajectory.

The Project Orion Crew Exploration Vehicle (CEV) was defined by NASA's Exploration Systems Architecture Study (Ref. 5) as NASA's next manned space vehicle. The CEV will support NASA's exploration missions by providing crew access to the International Space Station, the Moon, and Mars. The geometry of the CEV (Figure 2) is similar to that of Apollo - a spherical segment heat shield that protects a truncated-cone shaped crew compartment - but is considerably larger. The maximum diameter of the CEV is $5.0 \mathrm{~m}$ (current design), as compared to that of $3.912 \mathrm{~m}$ for Apollo. The design of the CEV's TPS must account for the high heating rates generated at lunar return velocities and the aerothermodynamic challenges of non-equilibrium thermo-chemistry, turbulent flow, and radiation transport. As with MSL, the CEV is being designed with the conservative assumption of fully-turbulent flow throughout its trajectory. Although not discussed herein, the CEV TPS design must also 
account for ablation effects, including shape change, flow field radiation-ablation coupling, and ablated surface roughness heating augmentation. An overview of the CEV design and development program is given in Ref. 6 and a summary of all CEV aerothermodynamic testing to date is presented in Ref. 7.
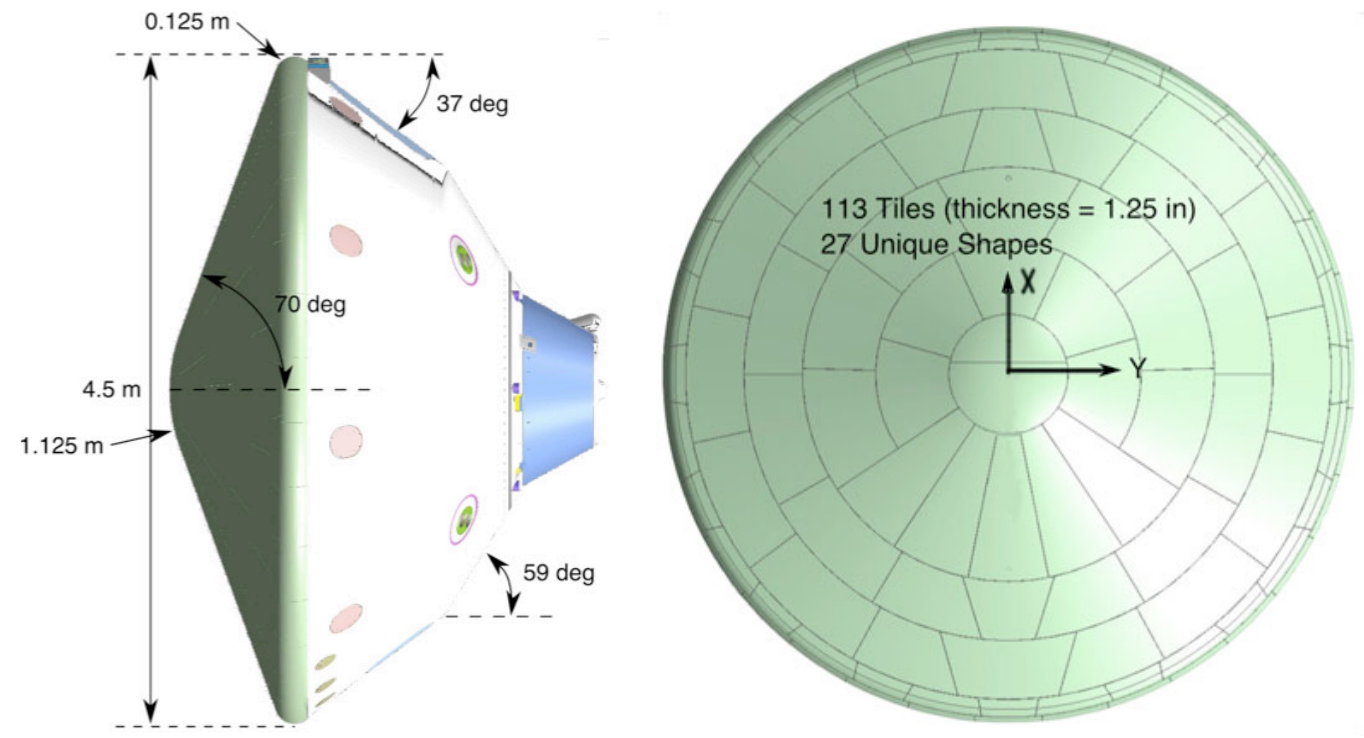

Figure 1. Mars Science Laboratory Entry Vehicle
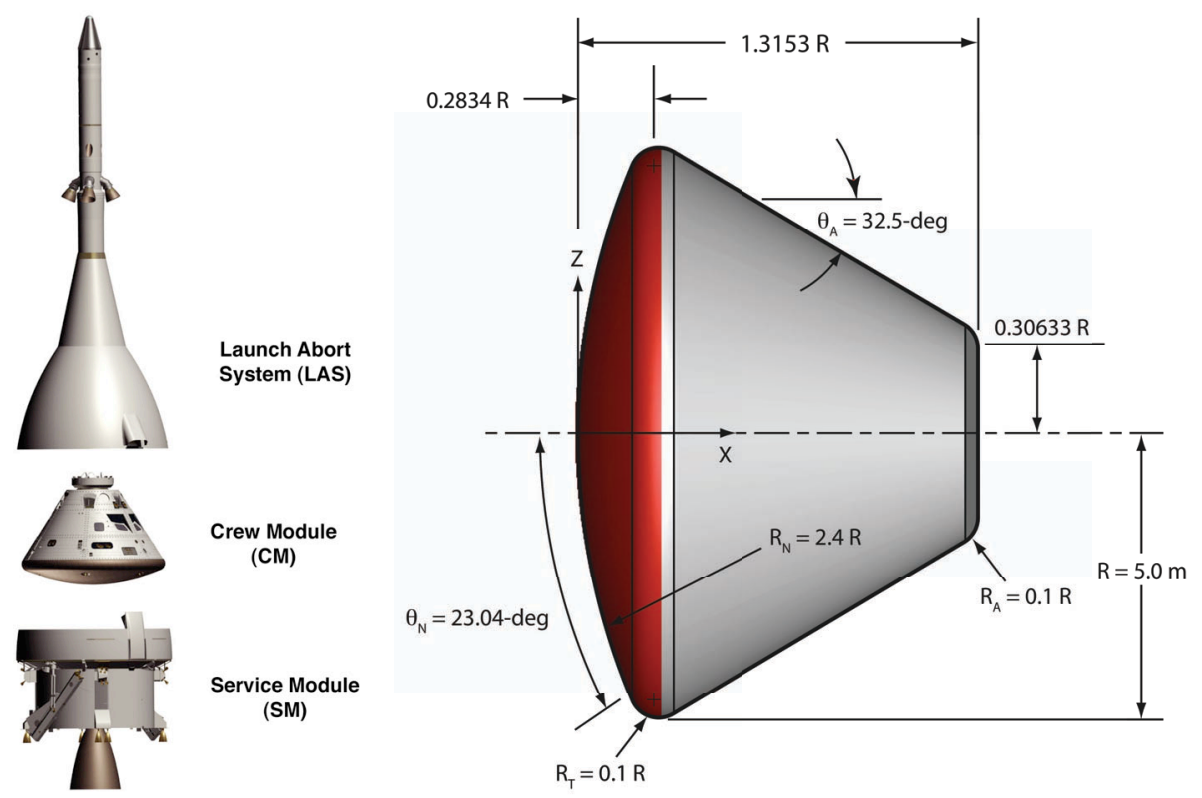

Figure 2. Project Orion CEV

\section{Survey of Blunt Body Turbulent Experimental Data Sources}

Extensive aerothermodynamic ground-testing has been conducted in support of both the MSL and CEV development program developments, including testing in the AEDC Hypervelocity Tunnel 9, CUBRC LENS I and 48-Inch Reflected Shock Tunnels, CalTech T5 Reflected Shock Tunnel, and the NASA Langley 20-Inch Mach 6 Air and 31-Inch Mach 10 Air Tunnels. In the analyses presented herein, only the test data obtained on smooth outermodel line (no penetrations, protrusions, roughness, or other effects, except for boundary-layer trips) models at perfect-gas conditions where transitional and/or turbulent data flow was produced were considered. These tests are summarized in Table 1. Nominal flow conditions for the data sets under consideration are listed in Table 2 for the 
AEDC Hypervelocity Tunnel 9, LENS I, and the NASA Langley 20-Inch Mach 6 Air Tunnel. Information on these facilities can be found in Refs. 8 - 10.

A brief discussion of each test entry along with sample data and comparisons will be presented below. More detailed results on model design, run schedules and exact test conditions, along with the full data sets, can be found in the references given. In subsequent sections, analyses and correlations for transition onset and turbulent heating augmentation that are based on the entire data set from all of the tests will be presented.

Table 1. Summary of CEV and MSL Tests with Transitional / Turbulent Data

\begin{tabular}{|c|c|c|c|c|c|c|c|c|}
\hline $\begin{array}{c}\text { Test } \\
\text { Facility }\end{array}$ & $\begin{array}{c}\text { Test } \\
\text { Number }\end{array}$ & Config. & $\begin{array}{l}\text { Model } \\
\text { diam. }\end{array}$ & $\alpha$ (deg) & \begin{tabular}{|c|} 
Model \\
fabrication
\end{tabular} & Instrumentation & Refs. & Notes \\
\hline $\begin{array}{c}\text { AEDC Tunnel } \\
\text { 9, Mach } 8 \text { and } \\
\text { Mach } 10\end{array}$ & $\mathrm{~N} / \mathrm{A}$ & MSL & 6-in. & $0-24$ & $\begin{array}{l}\text { Stainless } \\
\text { steel }\end{array}$ & $\begin{array}{l}\text { Coaxial surface } \\
\text { thermocouples }\end{array}$ & 11 & $\begin{array}{c}\text { High Reynolds } \\
\text { number turbulent } \\
\text { aeroheating }\end{array}$ \\
\hline $\begin{array}{c}\text { LaRC 20-Inch } \\
\text { Mach 6 Air } \\
\end{array}$ & Test 6827 & MSL & 5-in. & \begin{tabular}{|c|}
11,16 \\
20 \\
\end{tabular} & $\begin{array}{c}\text { Cast } \\
\text { ceramic }\end{array}$ & $\begin{array}{c}\text { Global phosphor } \\
\text { thermography }\end{array}$ & $12,13,14$ & $\begin{array}{c}\text { Boundary-layer } \\
\text { tripping }\end{array}$ \\
\hline $\begin{array}{c}\text { LaRC 20-Inch } \\
\text { Mach 6 Air } \\
\end{array}$ & Test 6884 & MSL & $\begin{array}{c}\text { 6-in. and } \\
7 \text {-in. } \\
\end{array}$ & 16,20 & $\begin{array}{c}\text { Cast } \\
\text { ceramic }\end{array}$ & $\begin{array}{c}\text { Global phosphor } \\
\text { thermography }\end{array}$ & 15 & $\begin{array}{c}\text { Transition and } \\
\text { turbulence }\end{array}$ \\
\hline $\begin{array}{c}\text { LaRC 20-Inch } \\
\text { Mach } 6 \text { Air }\end{array}$ & Test 6945 & MSL & $\begin{array}{l}\text { 7-in., 8- } \\
\text { in. and 9- } \\
\text { in. }\end{array}$ & 16 & $\begin{array}{c}\text { Cast } \\
\text { ceramic }\end{array}$ & $\begin{array}{r}\text { Glo } \\
\text { the }\end{array}$ & Herein & $\begin{array}{c}\text { Transition and } \\
\text { turbulence }\end{array}$ \\
\hline $\begin{array}{c}\text { AEDC Tunnel } \\
\text { 9, Mach } 8 \text { and } \\
\text { Mach } 10 \\
\end{array}$ & $39-\mathrm{CH}$ & $\mathrm{CEV}$ & 7-in. & $24-32$ & $\begin{array}{c}\text { Stainless } \\
\text { steel }\end{array}$ & $\begin{array}{l}\text { Coaxial s } \\
\text { thermoce }\end{array}$ & 16,17 & $\begin{array}{c}\text { High Reynolds } \\
\text { number turbulent } \\
\text { aeroheating } \\
\end{array}$ \\
\hline $\begin{array}{l}\text { CUBRC } \\
\text { LENS I }\end{array}$ & $67-\mathrm{CH}$ & $\mathrm{CEV}$ & 14-in. & 20,28 & $\begin{array}{c}\text { Stainless } \\
\text { steel }\end{array}$ & $\begin{array}{l}\text { Coaxial surface } \\
\text { thermocouples and thin- } \\
\text { film heat transfer gages }\end{array}$ & 18 & $\begin{array}{c}\text { High Reynolds } \\
\text { number turbulent } \\
\text { aeroheating }\end{array}$ \\
\hline $\begin{array}{c}\text { LaRC 20-Inch } \\
\text { Mach } 6 \text { Air } \\
\end{array}$ & $\begin{array}{c}\text { Test } 6917 \\
(31-\mathrm{CH})\end{array}$ & $\mathrm{CEV}$ & $\begin{array}{c}\text { 5-in., and } \\
7 \text {-in. }\end{array}$ & 28 & $\begin{array}{c}\text { Cast } \\
\text { ceramic }\end{array}$ & $\begin{array}{l}\text { Global phosphor } \\
\text { thermography }\end{array}$ & 19 & $\begin{array}{c}\text { Boundary-layer } \\
\text { tripping }\end{array}$ \\
\hline $\begin{array}{c}\text { LaRC 20-Inch } \\
\text { Mach 6 Air } \\
\end{array}$ & $\begin{array}{l}\text { Test 6931 } \\
(56-\mathrm{CH}) \\
\end{array}$ & $\mathrm{CEV}$ & 7-in. & $16-32$ & $\begin{array}{c}\text { Stainless } \\
\text { steel }\end{array}$ & $\begin{array}{l}\text { Coaxial surface } \\
\text { thermocouples }\end{array}$ & 20,21 & $\begin{array}{c}\text { Boundary-layer } \\
\text { tripping }\end{array}$ \\
\hline $\begin{array}{c}\text { LaRC 20-Inch } \\
\text { Mach } 6 \text { Air }\end{array}$ & Test 6944 & $\mathrm{CEV}$ & $\begin{array}{l}\text { 7-in., 8- } \\
\text { in. and 9- } \\
\text { in. }\end{array}$ & 28 & $\begin{array}{c}\text { Cast } \\
\text { ceramic }\end{array}$ & $\begin{array}{c}\text { Global phosphor } \\
\text { thermography }\end{array}$ & herein & $\begin{array}{l}\text { Transition and } \\
\text { turbulence }\end{array}$ \\
\hline
\end{tabular}

Table 2. Facility Test Conditions

\begin{tabular}{|c|c|c|c|c|c|c|c|c|c|}
\hline $\begin{array}{c}\text { Test } \\
\text { Facility }\end{array}$ & $\begin{array}{l}\text { Test } \\
\text { Gas }\end{array}$ & $\begin{array}{c}\mathrm{Re}_{\infty} \\
(1 / \mathrm{ft})\end{array}$ & $\begin{array}{l}\mathrm{Re}_{\mathrm{x}} \\
(1 / \mathrm{m})\end{array}$ & $\mathrm{M}_{x}$ & $\begin{array}{c}\mathrm{P}_{\infty} \\
(\mathrm{Pa})\end{array}$ & $\begin{array}{c}\mathrm{T}_{\infty} \\
(\mathrm{K})\end{array}$ & $\begin{array}{c}\rho_{\star} \\
\left(\mathrm{kg} / \mathrm{m}^{\wedge} 3\right)\end{array}$ & $\begin{array}{c}\mathrm{U}_{\infty} \\
(\mathrm{m} / \mathrm{s})\end{array}$ & $\begin{array}{c}\mathrm{H}_{0}-\mathrm{H}_{300 \mathrm{~K}} \\
(\mathrm{MJ} / \mathrm{kg})\end{array}$ \\
\hline AEDC Tunnel 9, Mach 8 & $\mathrm{~N} 2$ & $4.09 \mathrm{E}+06$ & $1.34 \mathrm{E}+07$ & 7. & 1171.1 & 74.4 & $5.305 \mathrm{E}-02$ & 1302.2 & $0.536 \mathrm{E}+06$ \\
\hline AEDC Tunnel 9, Mach 8 & $\mathrm{~N} 2$ & $5 \mathrm{E}+06$ & $2.74 \mathrm{E}+07$ & 7.4 & 2341.2 & 73.5 & $1.073 \mathrm{E}-01$ & 1301.1 & +06 \\
\hline AEDC Tunnel 9, Mach 8 & $\mathrm{~N} 2$ & $16.4 \mathrm{E}+06$ & $5.37 \mathrm{E}+07$ & 7.6 & 5177.9 & 81.1 & $2.152 \mathrm{E}-01$ & 1399.1 & $692 \mathrm{E}+06$ \\
\hline AEDC Tunnel 9, Mach 8 & $\mathrm{~N} 2$ & $21.6 \mathrm{E}+06$ & $7.08 \mathrm{E}+07$ & 7.8 & 6207.3 & 77.1 & $2.716 \mathrm{E}-01$ & 1390.0 & $0.674 \mathrm{E}+06$ \\
\hline AEDC Tunnel 9, Mach 8 & $\mathrm{~N} 2$ & $30.5 \mathrm{E}+06$ & $10.0 \mathrm{E}+07$ & 7.8 & 8236.8 & 73.8 & $3.766 \mathrm{E}-01$ & 1360.7 & $0.671 \mathrm{E}+06$ \\
\hline AEDC Tunnel 9, Mach 8 & $\mathrm{~N} 2$ & $48.6 \mathrm{E}+06$ & $16.0 \mathrm{E}+07$ & 8.0 & 11855.3 & 70.1 & 5.718 & 1356.8 & +06 \\
\hline 10 & $\mathrm{~N} 2$ & $2 \mathrm{E}+06$ & 97 & 9.6 & & 51.8 & 2 & .7 & +06 \\
\hline AEDC Tunnel 9, Mach 10 & $\mathrm{~N} 2$ & $1.90 \mathrm{E}+06$ & $0.62 \mathrm{E}+07$ & 9.6 & 272.9 & 55.6 & $1.653 \mathrm{E}-02$ & 1459.8 & $0.781 \mathrm{E}+06$ \\
\hline AEDC Tunnel 9, Mach 10 & $\mathrm{~N} 2$ & $4.67 \mathrm{E}+06$ & $1.53 \mathrm{E}+07$ & 9.9 & 606.7 & 52.9 & $3.863 \mathrm{E}-02$ & 1463.0 & $0.803 \mathrm{E}+06$ \\
\hline AEDC Tunnel 9, Mach 10 & $\mathrm{~N} 2$ & $8.79 \mathrm{E}+06$ & $2.88 \mathrm{E}+07$ & 10.1 & 1092.8 & 52.1 & 7.072E-02 & 1482.1 & +06 \\
\hline AEDC Tunne & $\mathrm{N} 2$ & $14.2 \mathrm{E}+06$ & $4.66 \mathrm{E}+07$ & 10.3 & 1588.1 & 49.3 & 1.086 & 1475.0 & +06 \\
\hline AEDC Tunnel 9, Mach 10 & $\mathrm{~N} 2$ & $20.0 \mathrm{E}+06$ & $6.56 \mathrm{E}+07$ & 10.4 & 2175.2 & 48.5 & 1.51 & 1472.2 & $0.805 \mathrm{E}+06$ \\
\hline LaRC 20-I & $\mathrm{Ai}$ & $E+06$ & 0.70 & 6.0 & 5 & 61.9 & 3.30 & 939.1 & 0.2 \\
\hline LaRC 20-Inch Mach 6 Air & Air & $2.61 \mathrm{E}+06$ & $0.86 \mathrm{E}+07$ & 6.0 & 723.2 & 62.2 & $4.050 \mathrm{E}-02$ & 943.0 & +06 \\
\hline LaRC 20-Inch Mach 6 Air & Air & $2.99 \mathrm{E}+06$ & $0.98 \mathrm{E}+07$ & 6.0 & 825.0 & 62.2 & 4.624E-02 & 945.5 & $0.209 \mathrm{E}+06$ \\
\hline LaRC 20-Inch Mach 6 Air & Air & $3.44 \mathrm{E}+06$ & $1.13 \mathrm{E}+07$ & 6.0 & 935.5 & 61.6 & $5.290 \mathrm{E}-02$ & 940.1 & $0.202 \mathrm{E}+06$ \\
\hline LaRC 20-Inch Mach 6 Air & Air & $3.88 \mathrm{E}+06$ & $1.27 \mathrm{E}+07$ & 6.0 & 1098.0 & 63.3 & $6.052 \mathrm{E}-02$ & 957.2 & $0.221 \mathrm{E}+06$ \\
\hline LaRC 20-Inch Mach 6 Air & Air & $4.13 \mathrm{E}+06$ & $1.36 \mathrm{E}+07$ & 6.0 & 1118.5 & 61.5 & $6.345 \mathrm{E}-02$ & 942.1 & $0.205 \mathrm{E}+06$ \\
\hline LaRC 20-Inch Mach 6 Air & Air & $4.63 \mathrm{E}+06$ & $1.52 \mathrm{E}+07$ & 6.0 & 1321.7 & 63.5 & $7.250 \mathrm{E}-02$ & 985.5 & $0.248 \mathrm{E}+06$ \\
\hline LaRC 20-Inch Mach 6 Air & Air & $5.09 \mathrm{E}+06$ & $1.67 \mathrm{E}+07$ & 6.0 & 1441.5 & 63.4 & $7.920 \mathrm{E}-02$ & 985.7 & $0.248 \mathrm{E}+06$ \\
\hline LaRC 20-Inch Mach 6 Air & Air & $5.76 \mathrm{E}+06$ & $1.89 \mathrm{E}+07$ & 6.0 & 6474.7 & 63.0 & $3.590 \mathrm{E}-01$ & 957.1 & $0.220 \mathrm{E}+06$ \\
\hline
\end{tabular}

4

American Institute of Aeronautics and Astronautics 


\begin{tabular}{cccccccccc}
\hline $\begin{array}{c}\text { Test } \\
\text { Facility }\end{array}$ & $\begin{array}{c}\mathrm{Test} \\
\mathrm{Gas}\end{array}$ & $\begin{array}{c}\mathrm{Re}_{\infty} \\
(1 / \mathrm{ft})\end{array}$ & $\begin{array}{c}\mathrm{Re}_{\infty} \\
(1 / \mathrm{m})\end{array}$ & $\mathrm{M}_{\infty}$ & $\begin{array}{c}\mathrm{P}_{\infty} \\
(\mathrm{Pa})\end{array}$ & $\begin{array}{c}\mathrm{T}_{\infty} \\
(\mathrm{K})\end{array}$ & $\begin{array}{c}\rho_{\infty} \\
(\mathrm{kg} / \mathrm{m} \wedge 3)\end{array}$ & $\begin{array}{c}\mathrm{U}_{\infty} \\
(\mathrm{m} / \mathrm{s})\end{array}$ & $\begin{array}{c}\mathrm{H}_{0}-\mathrm{H}_{300 K} \\
(\mathrm{MJ} / \mathrm{kg})\end{array}$ \\
\hline LaRC 20-Inch Mach 6 Air & Air & $6.63 \mathrm{E}+06$ & $2.18 \mathrm{E}+07$ & 6.0 & 1833.0 & 62.6 & $1.023 \mathrm{E}-01$ & 954.6 & $0.217 \mathrm{E}+06$ \\
LaRC 20-Inch Mach 6 Air & Air & $7.32 \mathrm{E}+06$ & $2.40 \mathrm{E}+07$ & 6.1 & 2032.0 & 62.7 & $1.130 \mathrm{E}-01$ & 956.8 & $0.220 \mathrm{E}+06$ \\
LaRC 20-Inch Mach 6 Air & Air & $7.46 \mathrm{E}+06$ & $2.45 \mathrm{E}+07$ & 6.0 & 2058.0 & 62.5 & $1.154 \mathrm{E}-01$ & 953.6 & $0.217 \mathrm{E}+06$ \\
& & & & & & & & & \\
CUBRC LENS I & Air & $8.65 \mathrm{E}+05$ & $0.28 \mathrm{E}+07$ & 7.6 & 260.8 & 79.8 & $1.134 \mathrm{E}-02$ & 1371.4 & $0.719 \mathrm{E}+06$ \\
CUBRC LENS I & Air & $9.40 \mathrm{E}+05$ & $0.31 \mathrm{E}+07$ & 7.7 & 231.0 & 70.6 & $1.134 \mathrm{E}-02$ & 1304.5 & $0.620 \mathrm{E}+06$ \\
CUBRC LENS I & Air & $9.51 \mathrm{E}+05$ & $0.31 \mathrm{E}+07$ & 7.7 & 238.3 & 71.5 & $1.154 \mathrm{E}-02$ & 1312.7 & $0.632 \mathrm{E}+06$ \\
CUBRC LENS I & Air & $7.92 \mathrm{E}+06$ & $2.60 \mathrm{E}+07$ & 7.7 & 2178.7 & 75.8 & $9.947 \mathrm{E}-02$ & 1353.3 & $0.691 \mathrm{E}+06$ \\
CUBRC LENS I & Air & $23.4 \mathrm{E}+06$ & $7.68 \mathrm{E}+07$ & 8.0 & 6095.0 & 78.9 & $3.036 \mathrm{E}-01$ & 1420.4 & $0.787 \mathrm{E}+06$ \\
CUBRC LENS I & Air & $25.8 \mathrm{E}+06$ & $8.46 \mathrm{E}+07$ & 8.1 & 5364.1 & 65.6 & $2.835 \mathrm{E}-01$ & 1316.7 & $0.631 \mathrm{E}+06$ \\
CUBRC LENS I & Air & $26.3 \mathrm{E}+06$ & $8.63 \mathrm{E}+07$ & 8.1 & 5968.6 & 69.1 & $2.991 \mathrm{E}-01$ & 1346.2 & $0.674 \mathrm{E}+06$ \\
CUBRC LENS I & Air & $30.4 \mathrm{E}+06$ & $9.96 \mathrm{E}+07$ & 8.2 & 7411.9 & 73.1 & $3.525 \mathrm{E}-01$ & 1400.6 & $0.753 \mathrm{E}+06$ \\
CUBRC LENS I & Air & $32.5 \mathrm{E}+06$ & $10.7 \mathrm{E}+07$ & 8.0 & 8756.3 & 76.1 & $3.979 \mathrm{E}-01$ & 1396.0 & $0.749 \mathrm{E}+06$ \\
\hline
\end{tabular}

\section{MSL Turbulent Aeroheating Data}

\section{A. MSL Turbulent Aeroheating in AEDC Hypervelocity Tunnel 9}

An investigation (Ref. 11) of turbulent aeroheating on the MSL vehicle was conducted in the Arnold Engineering Development Center (AEDC) Hypervelocity Wind Tunnel No. 9. In this study, aeroheating data were collected on a 6-in. $(0.1524 \mathrm{~m})$ diameter coaxial thermocouple instrumented MSL model in perfect-gas $\mathrm{N}_{2}$ flow at the tunnels Mach 8 and Mach 10 test conditions. Data were obtained at free stream Reynolds numbers of $4 \times 10^{6} / \mathrm{ft}$ to $49 \times 10^{6} / \mathrm{ft}$ at Mach 8 and at $1 \times 10^{6} / \mathrm{ft}$ to $19 \times 10^{6} / \mathrm{ft}$ at Mach 10 with angles-of-attack between 0 -deg and 24-deg. Turbulent flow was produced over the leeside of the heat shield at the highest Mach 10 Reynolds number and turbulent flow was produced over the entire heat shield (both leeside and wind-side) at the highest Mach 8 Reynolds number. The experimental uncertainty of the data was estimated to be $\pm 12 \%$.

Laminar and turbulent perfect-gas comparisons to these data were performed using the LAURA code (Ref. 22) with the algebraic Cebeci-Smith turbulent model for the turbulent cases. Comparisons between centerline data and predictions are shown for selected $\alpha=16$-deg cases in Figure 3 and Figure 4. For the Mach 10 cases, the laminar predictions and data were in close agreement at $\mathrm{Re}_{\mathrm{s}}=4 \times 10^{6} / \mathrm{ft}$ case, while at $\mathrm{Re}_{\mathrm{s}}=19 \times 10^{6} / \mathrm{ft}$, the laminar predictions matched the data on the wind-side of the forebody and the turbulent predictions matched the data on the leeside. For both Mach 8 cases, the turbulent predictions matched the data. Although the agreement between predictions and data was generally good for these cases, there were discrepancies around the stagnation point $(x / R \sim-0.4)$ for all cases where measured heating rates were considerably higher than either laminar or turbulent predictions.
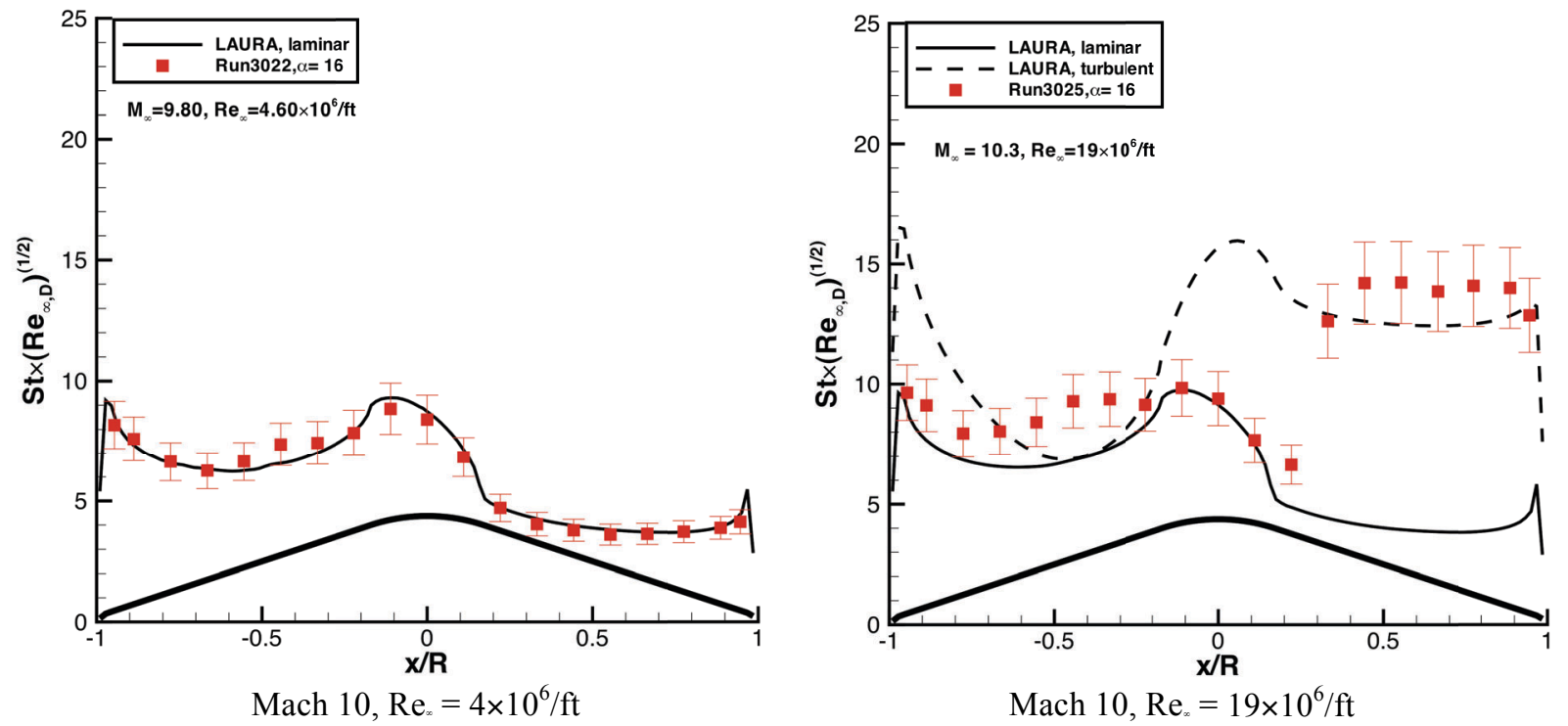

Figure 3. MSL Data and Comparisons from AEDC Tunnel 9 at Mach 10, $\alpha=16-d e g$

5

American Institute of Aeronautics and Astronautics 


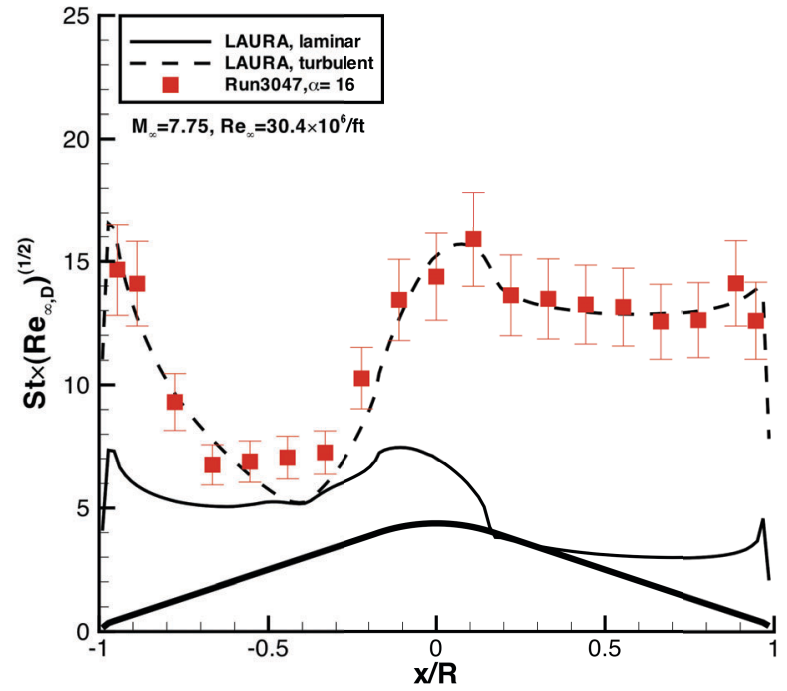

Mach $8, \operatorname{Re}_{x}=30 \times 10^{6} / \mathrm{ft}$

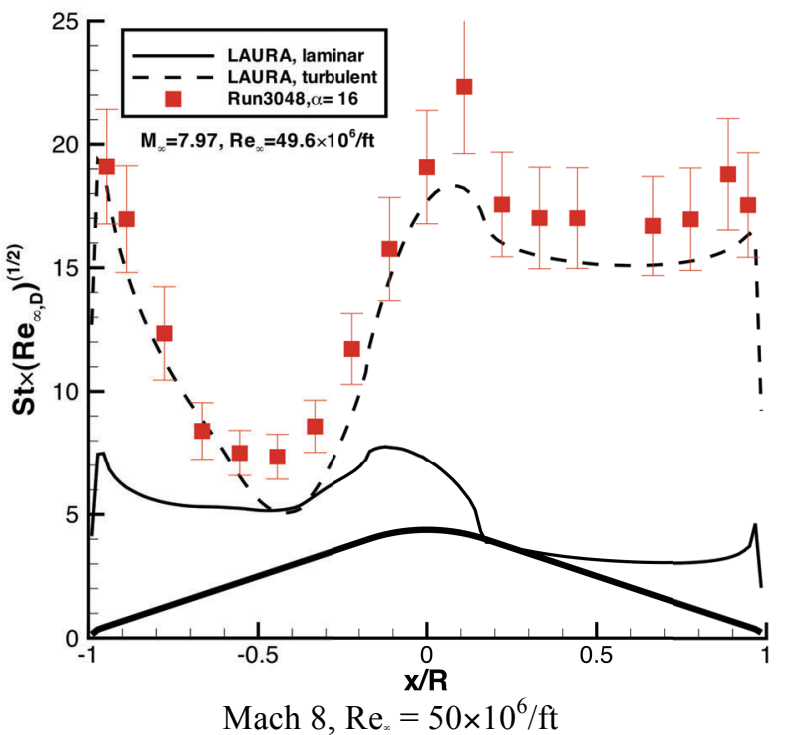

Mach 8, $\operatorname{Re}_{x}=50 \times 10^{6} / \mathrm{ft}$

Figure 4. MSL Data and Comparisons from AEDC Tunnel 9 at Mach 8, $\alpha=16-\mathrm{deg}$

\section{B. MSL Transitional/Turbulent Aeroheating in the NASA Langley 20-Inch Mach 6 Air Tunnel}

Several test programs were performed in the Langley 20-Inch Mach 6 Air Tunnel. In all cases, testing was performed with global thermography on phosphor-coated ceramic MSL models. The experimental uncertainty of the resulting data was estimated to be $\pm 10-15 \%$.

\section{Test 6827 - Cavity effects on heating and transition}

An extensive test program (Refs. 12,13,14) was conducted during the configuration development phase of the MSL program to determine the heating augmentation and boundary-layer transition influence of circular cavities on the vehicle's heat shield. These cavities were attachment points to the spacecraft cruise module that were located on the heat shield in early version of the MSL design, but were subsequently moved to the aftbody of the entry vehicle where they will have minimal effects on heating. Data were obtained at free stream Reynolds numbers of $2.0 \times 10^{6} / \mathrm{ft}$ to $5.8 \times 10^{6} / \mathrm{ft}$ at angles of attack of 11,16 , and 20-deg on 5-in. diameter models. Although the majority of these tests were conducted on models with the attachment point cavities, a limited number of runs were made using smooth surface models that had an array of boundary-layer trips located to the leeside of the nose. These previously unreported runs were part of Test 6827 and are shown here for the first time for use in the current analysis. The transitional / turbulent data from these runs are plotted in Figure 5 along with comparison to laminar LAURA predictions (no turbulent predictions were performed). The trips appeared to produce fully-turbulent flow when located at the nose/cone tangency point but not when located midway down the conical section.

\section{Test 6884 - Transition and turbulence with cone-angle parametrics}

In Test 6884, a parametric investigation of the effects of cone angle on transition and turbulent heating was conducted. MSL 70-deg sphere-cone models of 6-in. and 7-in. (along with 6-in. diam. 50-deg and 60-deg. spherecone models) were tested at free stream Reynolds numbers of $2.0 \times 10^{6} / \mathrm{ft}$ to $7.3 \times 10^{6} / \mathrm{ft}$ at angles of attack of 11,16 and 20-deg. Sample results are shown in Figure 6 and addition data are presented in Ref. 15. Transitional flow occurred on both size models, but fully-developed turbulent flow was not produced.

\section{Test 6945 - Model size effects on blockage and transition}

The inability to generate turbulent flow on the MSL configuration without using boundary-layer trips in previous tests led to an investigation (Test 6945) into the possibility of using larger diameter models to produce turbulent flow without adversely affecting the test section flow field. MSL models of 7-in., 8-in. and 9-in. model diameters were tested at $\alpha=16$-deg at free stream Reynolds numbers of $2.0 \times 10^{6} / \mathrm{ft}$ to $7.5 \times 10^{6} / \mathrm{ft}$. Data from this test are presented for the first time here in Figure 7 and comparisons with LAURA predictions are shown in Figure 8. It was found the 9-inch model caused definite flow blockage and thus good quality data could not be obtained on this model, but the 8-inch model appeared to have no effect on flow quality and turbulent flow was observed on the outer leeside portion of the cone. However, the data were approximately $15 \%$ to $20 \%$ higher than turbulent predictions. 
Possibly these difference were due to the fact that the solutions were generated with turbulent flow over the entire body, whereas the data indicate that transition occurred just downstream of the nose/cone tangency point. The 7-in. diameter model data were similar to those from previous tests.

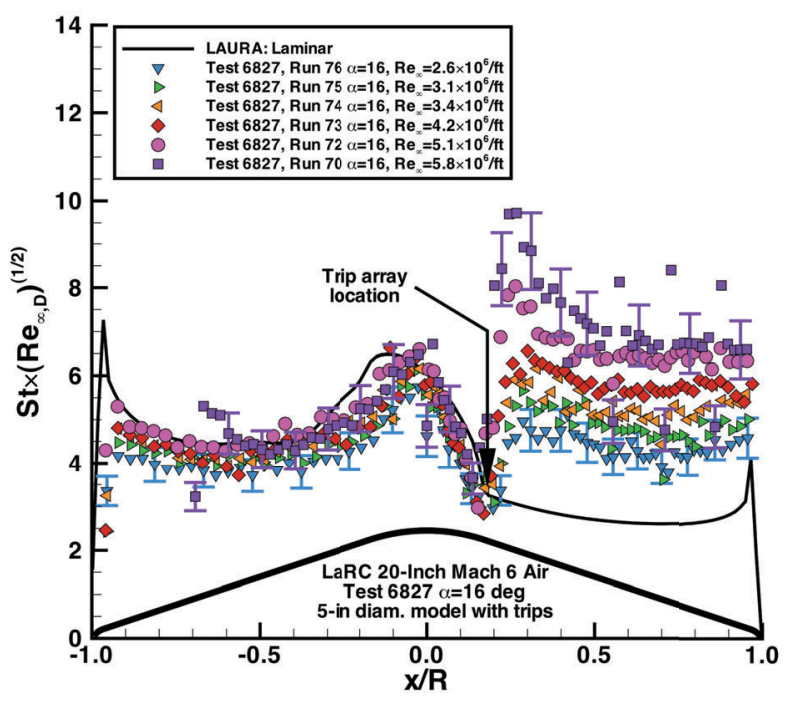

5-inch diameter model, $\alpha=16$-deg, trip array at nose/cone tangency point

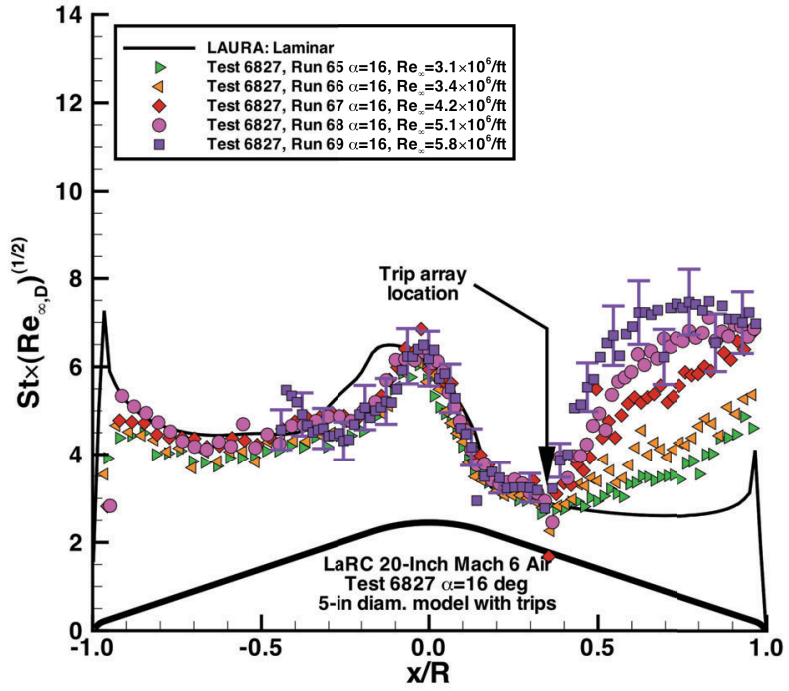

5-inch diameter model, $\alpha=16$-deg, trips midway along conical section

Figure 5. MSL $\alpha=16-d e g$ Data and Comparisons from LaRC 20-Inch Mach 6 Air Test 6827

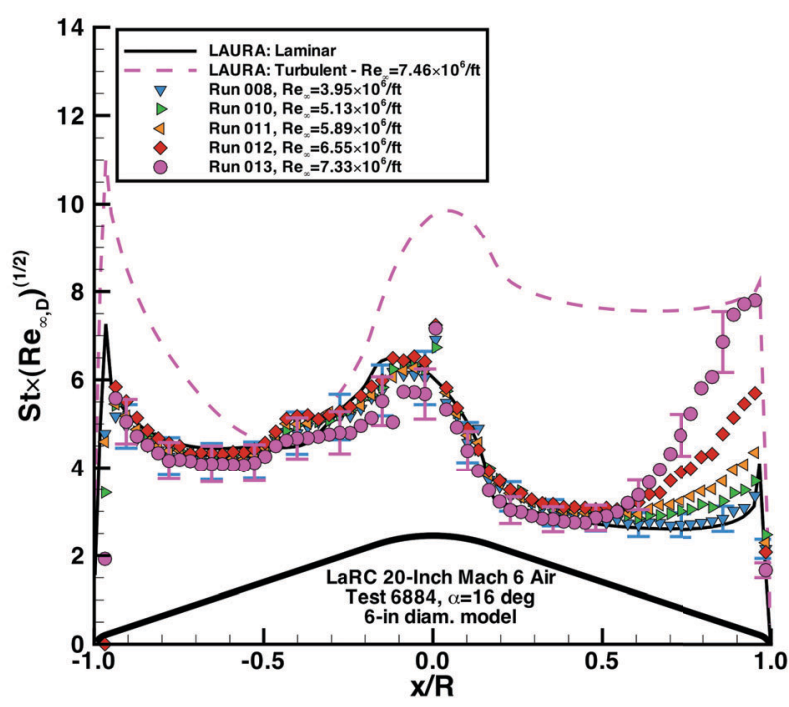

6-inch diameter model, $\alpha=16$-deg

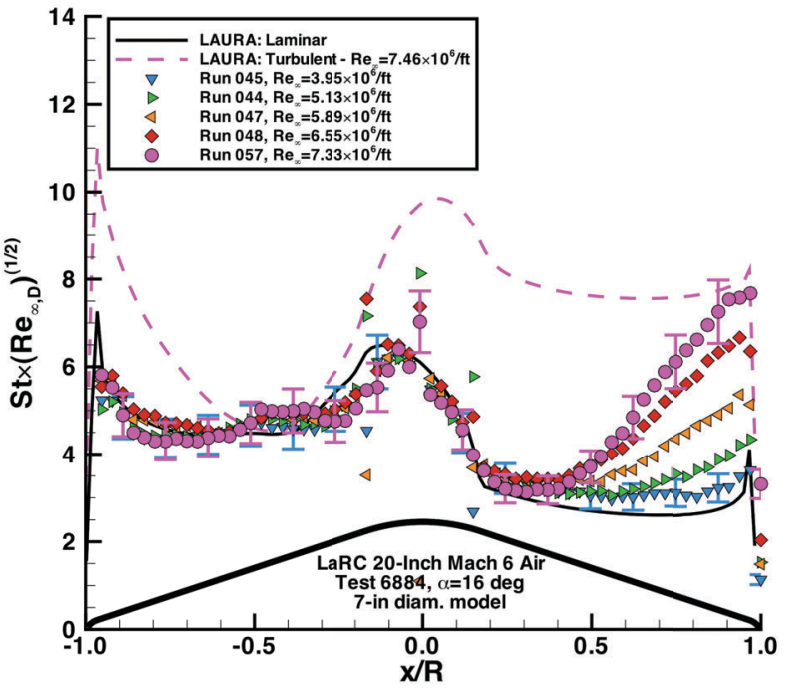

7-inch diameter model, $\alpha=16$-deg

Figure 6. MSL $\alpha=16-d e g$ Data and Comparisons from LaRC 20-Inch Mach 6 Air Test 6884 

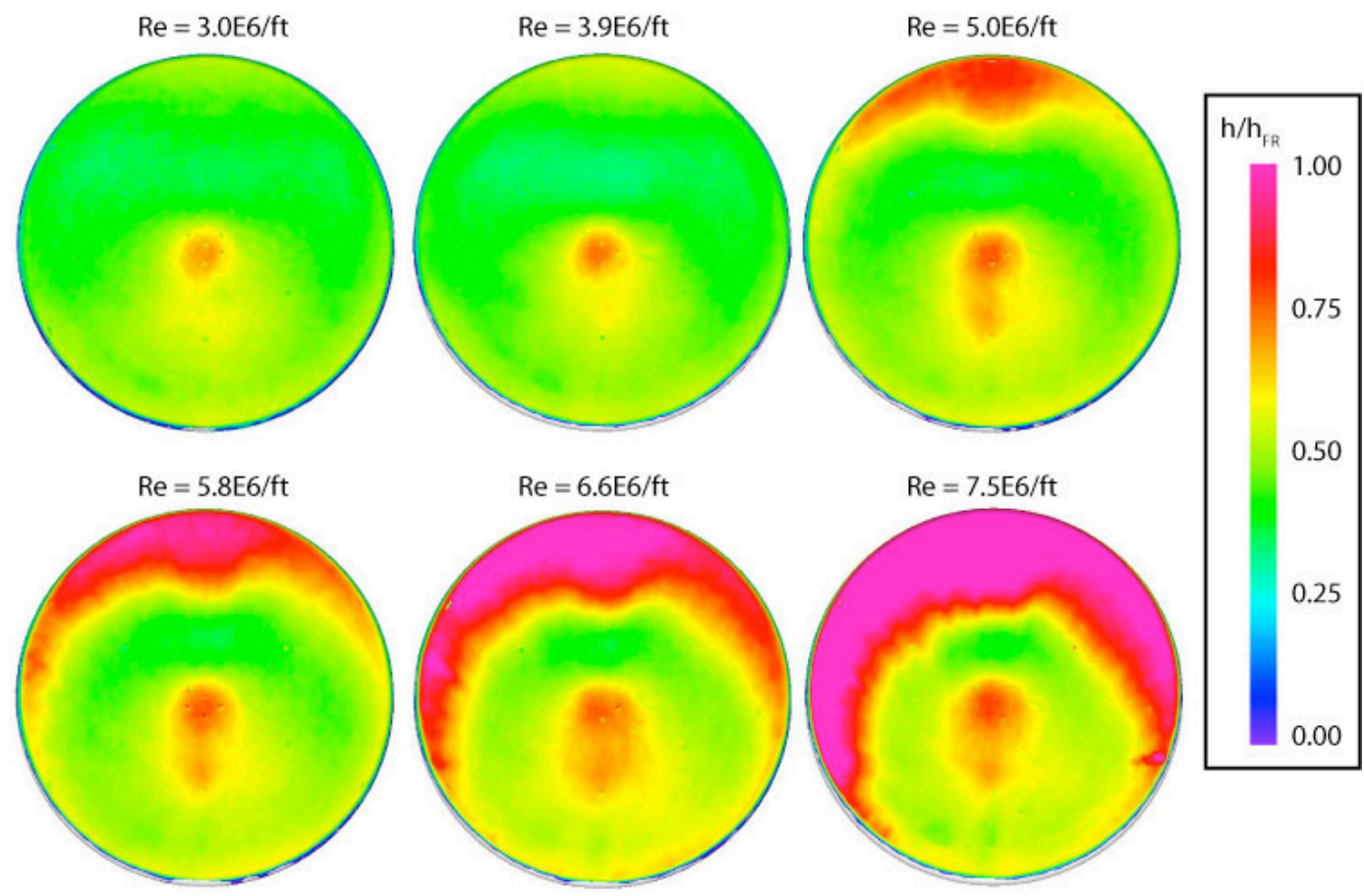

Figure 7. MSL Global Heating Data from Test 6945: 8-inch diameter model

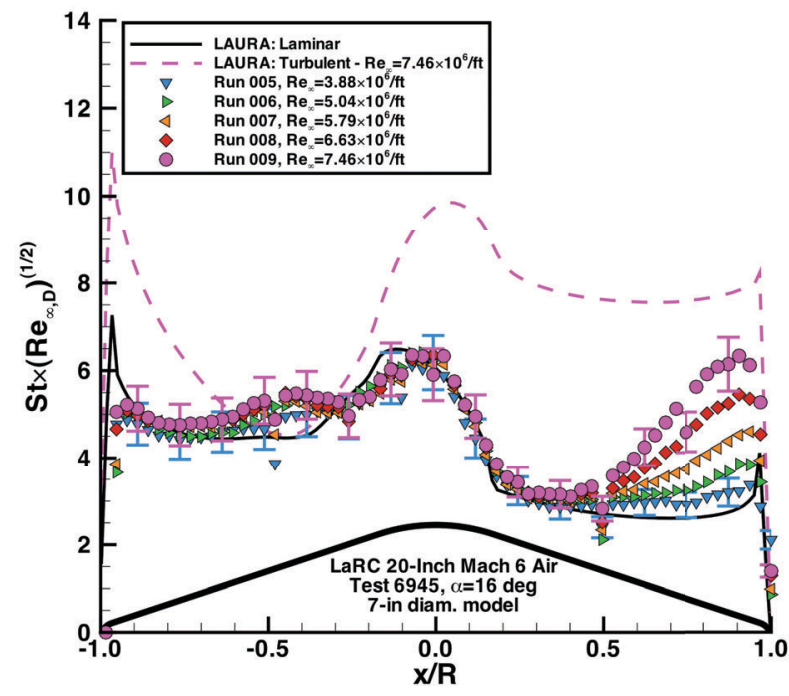

7-inch diameter model, $\alpha=16$-deg

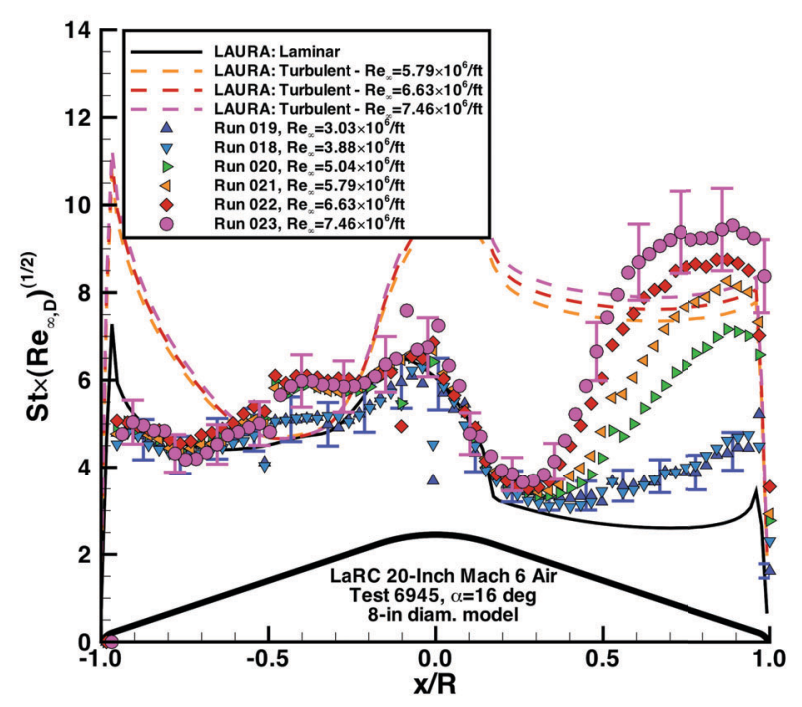

8-inch diameter model, $\alpha=16$-deg

Figure 8. MSL $\alpha=16-d e g$ Data and Comparisons from LaRC 20-Inch Mach 6 Air Test 6945

\section{CEV Turbulent Aeroheating Data}

\section{A. CEV Turbulent Aeroheating at AEDC Hypervelocity Tunnel 9}

Turbulent aeroheating testing (Refs. 16, 17) of the Orion CEV vehicle was conducted in the AEDC Hypervelocity Wind Tunnel No. 9 on a 7 -inch diameter, thermocouple-instrumented model in perfect-gas $\mathrm{N}_{2}$ flow at the tunnels Mach 8 and Mach 10 test conditions. Angles-of-attack were varied from 16-deg to 32-deg. Free stream Reynolds numbers ranged from $8 \times 10^{6} / \mathrm{ft}$ to $48 \times 10^{6} / \mathrm{ft}$ at Mach 8 and from $2 \times 10^{6} / \mathrm{ft}$ to $20 \times 10^{6} / \mathrm{ft}$ at Mach 10 . Transitional or turbulent flow was produced on the heat shield leeside for $\mathrm{Re}_{\mathrm{e}} \geq 10 \times 10^{6} / \mathrm{ft}$ for both Mach 8 and Mach 
10, and for the higher Mach 8 Reynolds numbers, turbulent flow was also produced on the wind side of the heat shield. The experimental uncertainty of the data was estimated to be $\pm 12 \%$.

Laminar and turbulent perfect-gas comparisons to these data were performed using the LAURA code with the algebraic Cebeci-Smith turbulent model being used for the turbulent cases. Comparisons between centerline data and predictions are shown for selected $\alpha=28$-deg cases in Figure 9 and Figure 10. For the Mach 10 cases, the laminar predictions and data were in close agreement at the $\operatorname{Re}_{x}=4 \times 10^{6} / \mathrm{ft}$ case, while at $\operatorname{Re}_{x}=19 \times 10^{6} / \mathrm{ft}$, the laminar predictions matched the data on the wind-side of the forebody and the turbulent predictions matched the data on the leeside. For both Mach 8 cases, the turbulent predictions matched the data.

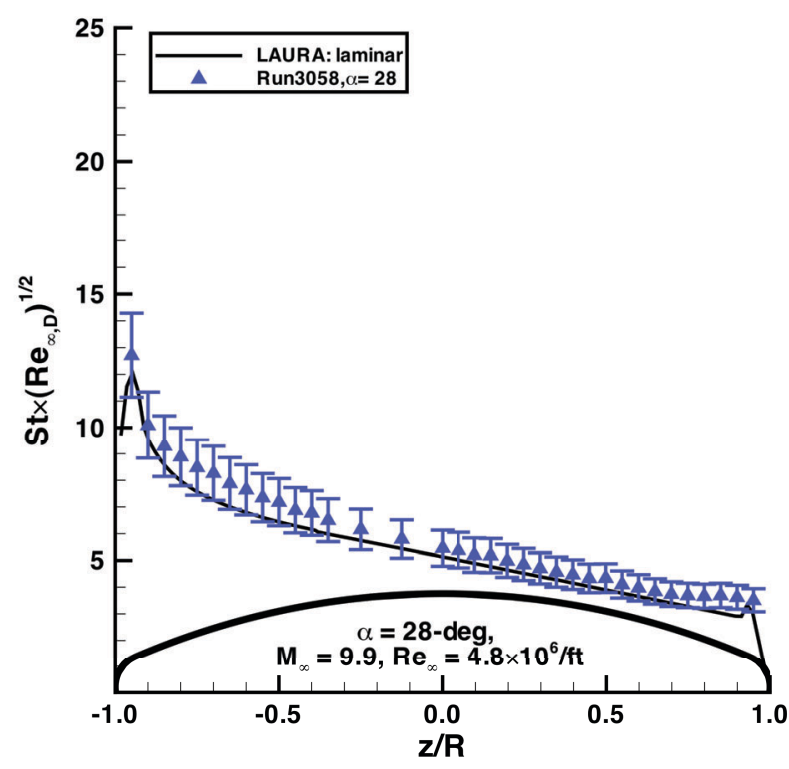

Mach 10, $\operatorname{Re}_{x}=4 \times 10^{6} / \mathrm{ft}$

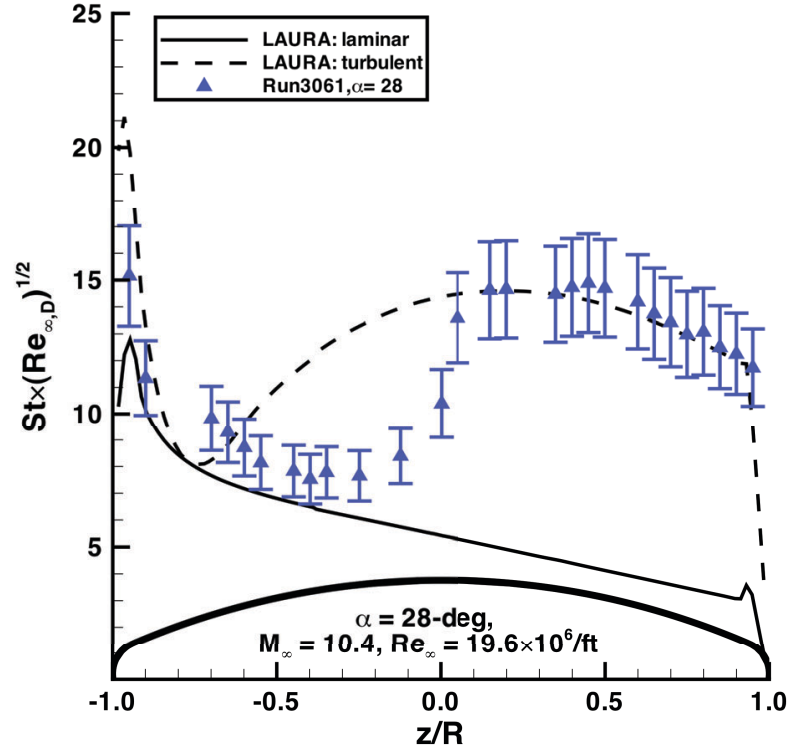

Mach 10, $\operatorname{Re}_{\mathrm{s}}=20 \times 10^{6} / \mathrm{ft}$

Figure 9. CEV Mach 10, $\alpha=28$-deg Data and Comparisons from AEDC Tunnel 9

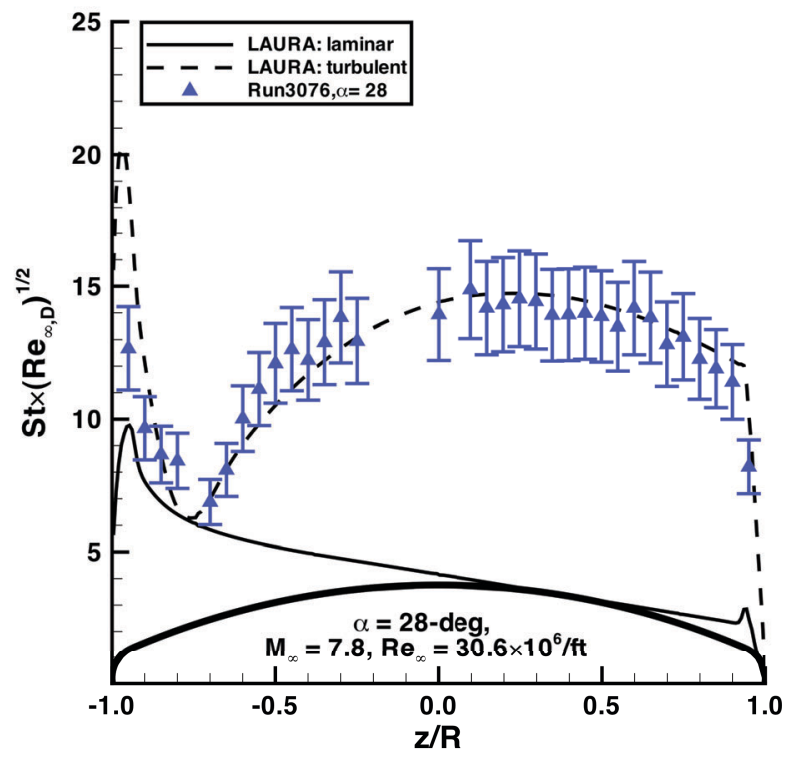

Mach 8, $\operatorname{Re}_{\mathrm{s}}=31 \times 10^{6} / \mathrm{ft}$

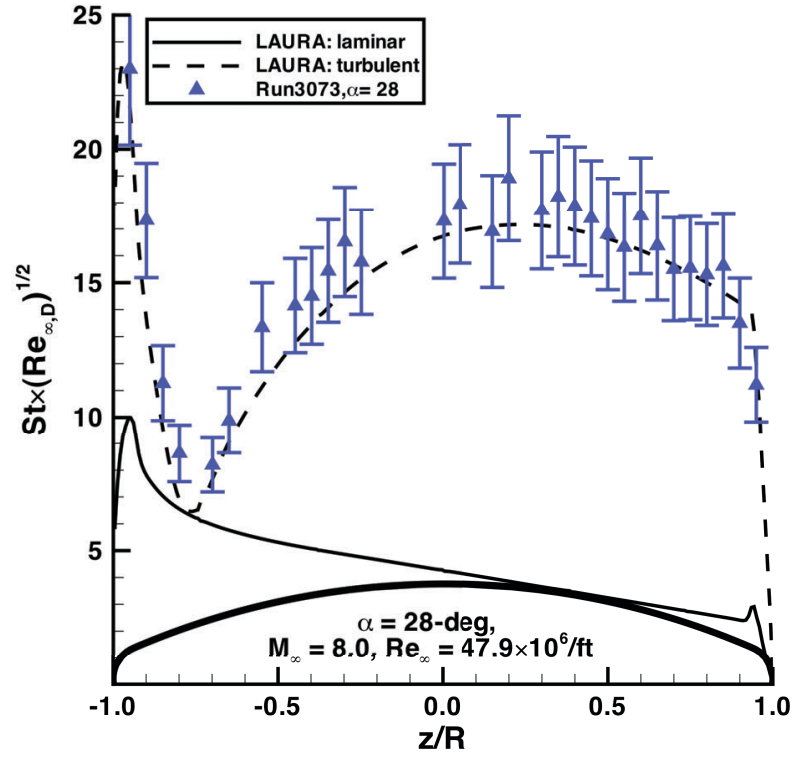

Mach 8, $\operatorname{Re}_{s}=48 \times 10^{6} / \mathrm{ft}$

Figure 10. CEV Mach 10, $\alpha=28-d e g$ Data and Comparisons from AEDC Tunnel 9 


\section{B. CEV Turbulent Aeroheating at CUBRC LENS}

Additional high Reynolds number turbulent aeroheating testing of the CEV was performed in the CUBRC LENS I reflected shock tunnel (Ref. 18) to supplement the AEDC test with data at lower $(\alpha=20$-deg) angle of attack. Data were obtained with a mix of coaxial surface thermocouples and thin-film heat-transfer gages on a 14-in. diam. stainless steel model. Runs were performed at free stream Reynolds numbers of $0.9 \times 10^{6} / \mathrm{ft}$ to $32 \times 10^{6} / \mathrm{ft}$. Fullyturbulent flow was produced over the entire forebody at the highest Reynolds numbers and close agreement between predictions and data were obtained, as shown in Figure 11.

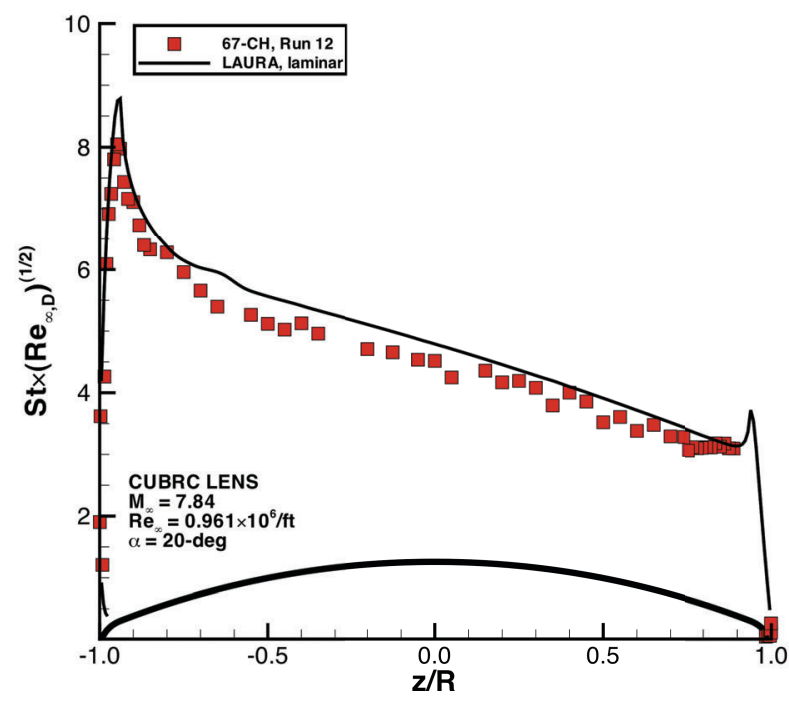

Mach 8, $\operatorname{Re}_{\infty}=0.96 \times 10^{6} / \mathrm{ft}$, laminar data

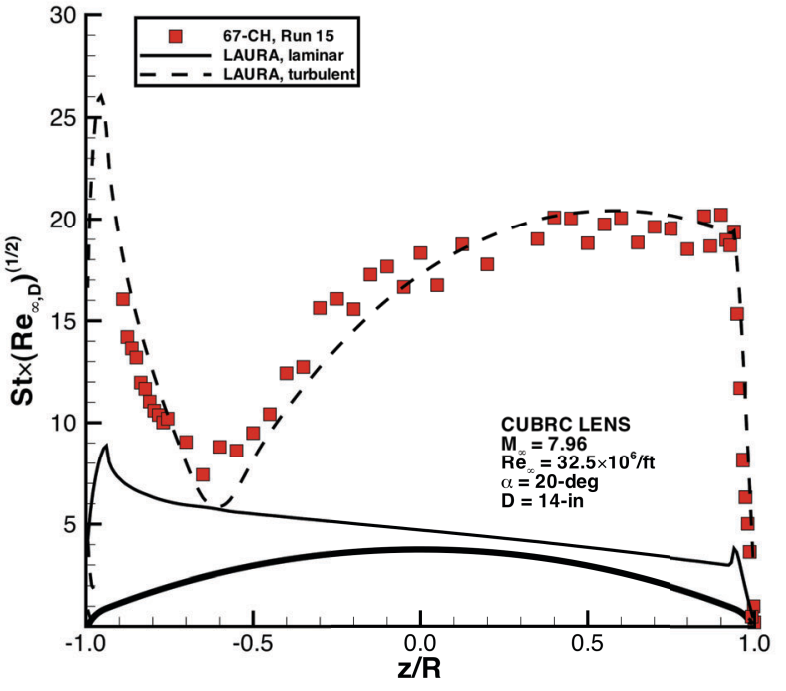

Mach $8, \operatorname{Re}_{\mathrm{s}}=32 \times 10^{6} / \mathrm{ft}$, turbulent data

Figure 11. CEV Mach 8, $\alpha=20-d e g$ Data and Comparisons from CUBRC LENS Test 67-CH

\section{CEV Transitional/Turbulent Aeroheating in the NASA Langley 20-Inch Mach 6 Air Tunnel}

Several CEV tests were performed in the Langley 20-Inch Mach 6 Air Tunnel using both stainless-steel, thermocouple-instrumented models and phosphor-coated, cast ceramic models with global thermography. The experimental uncertainty of the resulting data was estimated to be $\pm 10 \%$ to $15 \%$.

\section{Test 6917 - Boundary-layer tripping}

In Test 6917, turbulent flow was produced on the leeside of the 7-in. diam. CEV models using arrays of boundary layer trips. Data were obtained at $\alpha=28$-deg at free stream Reynolds numbers of $2.1 \times 10^{6} / \mathrm{ft}$ to $7.3 \times 10^{6} / \mathrm{ft}$ as reported in Ref. 19. Laminar and turbulent (with the Cebeci-Smith algebraic model) predictions were performed using LAURA and close agreement was obtained as shown in Figure 12.

\section{Tests 6931 and 6932 - Boundary-layer tripping}

In Test 6931 and 6932, the coaxial-instrumented, 7-in. diam. CEV model tested at AEDC Tunnel 9 was tested in the Langley 20-Inch Mach 6 Air Tunnel. Test 6931 was a checkout of the model (Ref. 20) and Test 6932 (Ref. 21) was a study of the effects of boundary-layer tripping on both the forebody and aftbody of the model. Runs were performed in both static and continuous pitch-mode over an angle-of-attack range of 16-deg to 32-deg free stream Reynolds numbers of $2.1 \times 10^{6} / \mathrm{ft}$ to $7.3 \times 10^{6} / \mathrm{ft}$. Sample data and comparisons are given in Figure 13 .

\section{Test 6944 - Model size effects on blockage and transition}

In conjunction with the model size blockage and transition testing conducted for MSL (Test 6945), a similar investigation was performed for the CEV configuration. CEV models of 7-in., 8-in. and 9-in. diameters were tested at $\alpha=28$-deg at free stream Reynolds numbers of $2.0 \times 10^{6} / \mathrm{ft}$ to $7.5 \times 10^{6} / \mathrm{ft}$. These Test 6944 data are presented for the first time herein in Figure 14. As with the MSL blockage study, the 9-in. diam. CEV model caused tunnel blockage and unsteady flow conditions. However, the 7-in. and 8-in. diameter models were successfully run and fully turbulent flow was produced on the leeside of the forebody at the highest test Reynolds numbers as shown in Figure 15. 


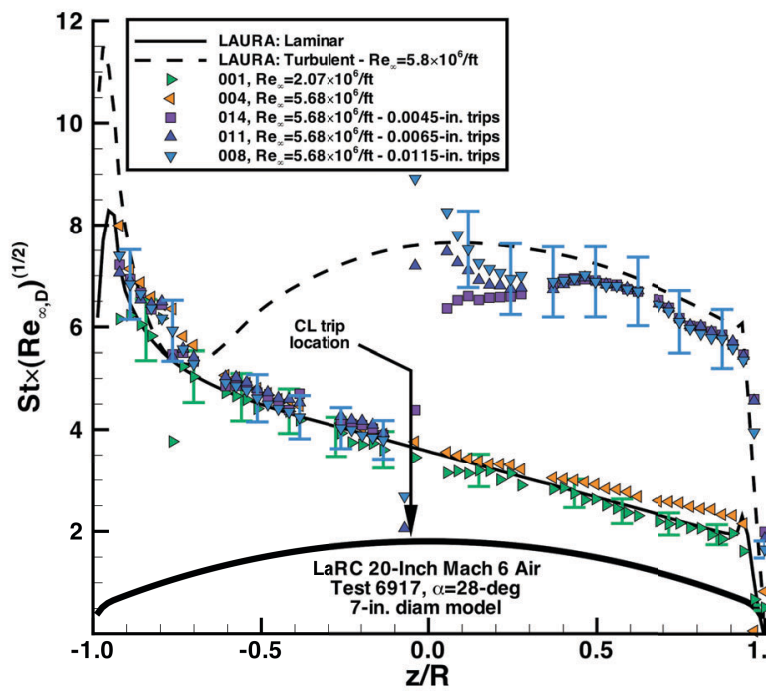

7-inch diameter model, $\alpha=28$-deg, $\operatorname{Re}_{\infty}=5.6 \times 10^{6} / \mathrm{ft}$

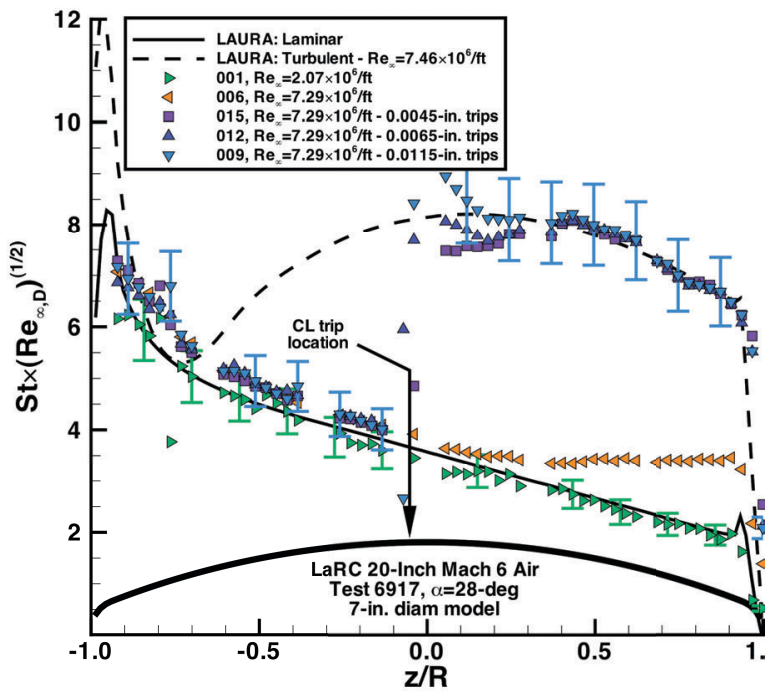

7-inch diameter model, $\alpha=28-\mathrm{deg}, \operatorname{Re}_{x}=7.4 \times 10^{6} / \mathrm{ft}$

Figure 12. CEV $\alpha=28$-deg Data and Comparisons from LaRC 20-Inch Mach 6 Air Test 6917

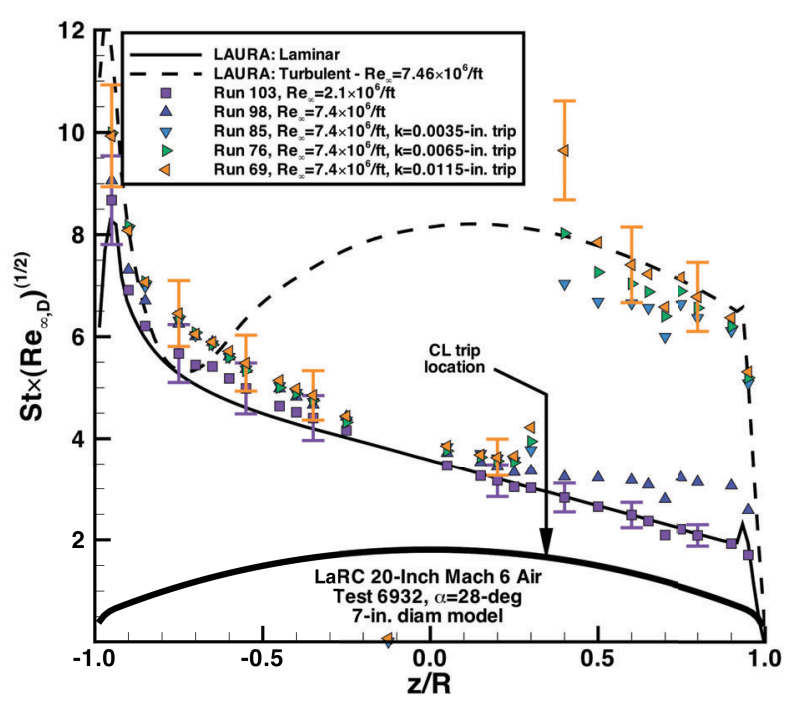

7-inch diameter model, $\alpha=28$-deg, trip array on positive side of symmetry axis

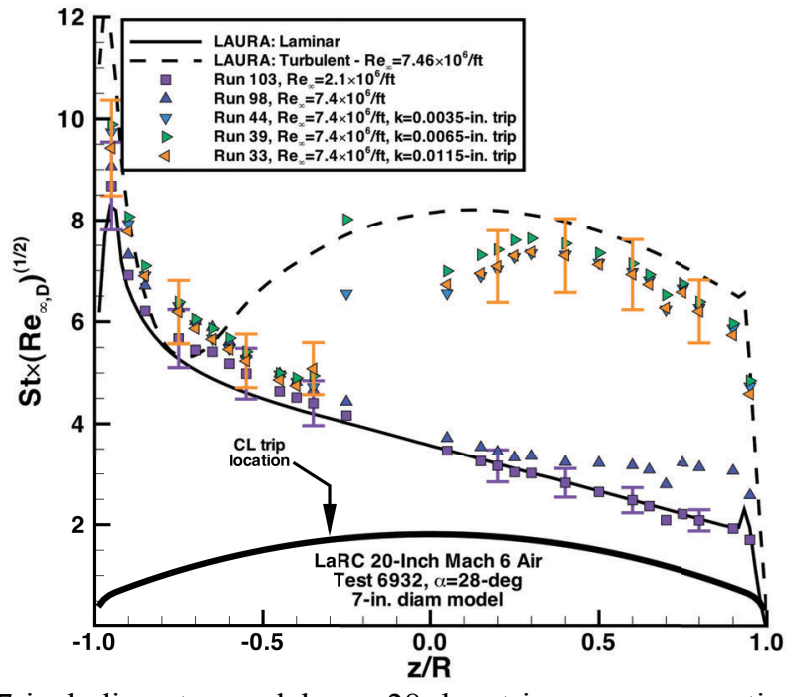

7-inch diameter model, $\alpha=28$-deg, trip array on negative side of symmetry axis

Figure 13. CEV $\alpha=28-d e g$ Data and Comparisons from LaRC 20-Inch Mach 6 Air Test 6932 

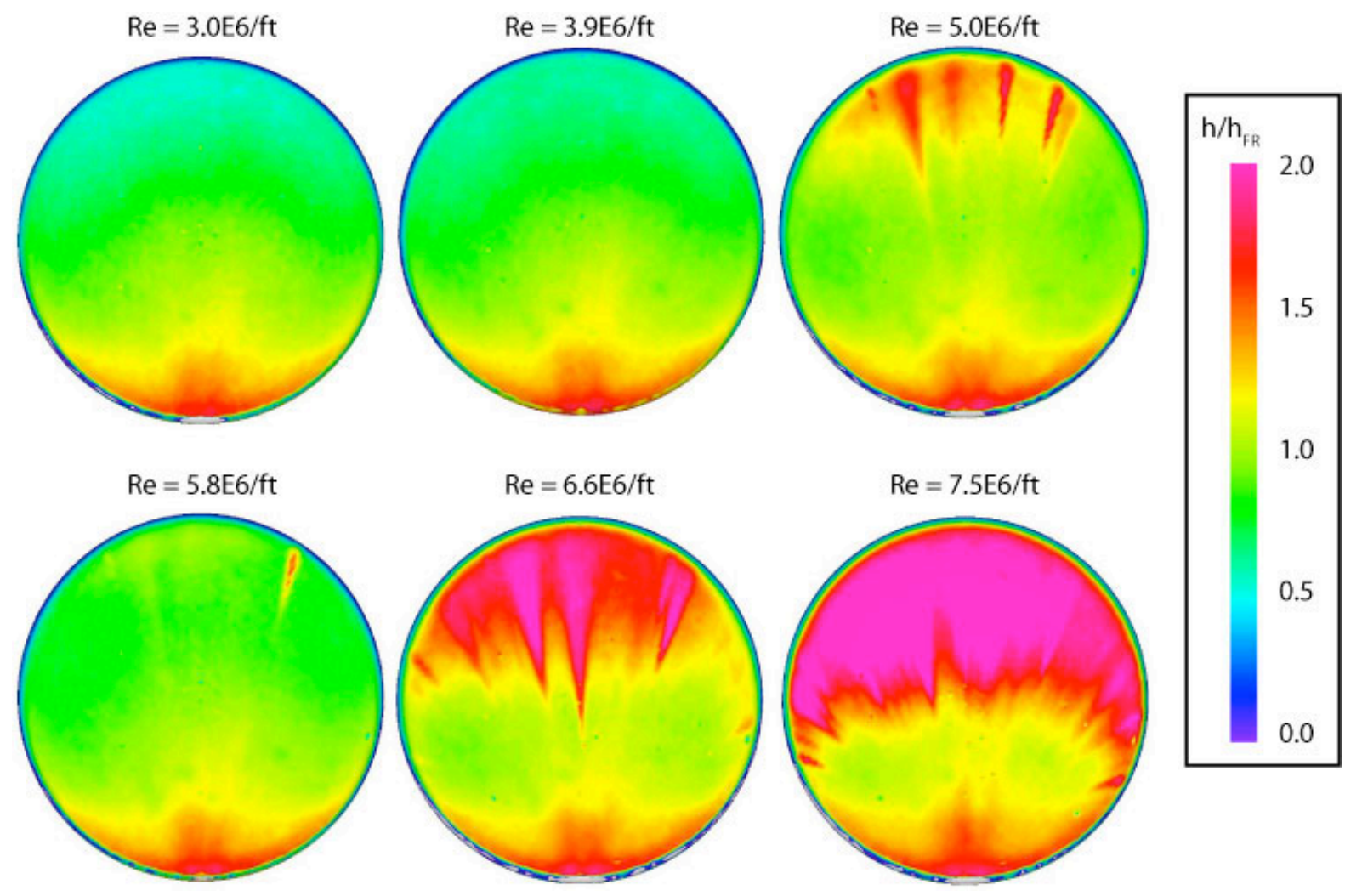

Figure 14. CEV Global Heating Distribution from Test 6944, $\alpha=28$-deg, 8-in. diam. model

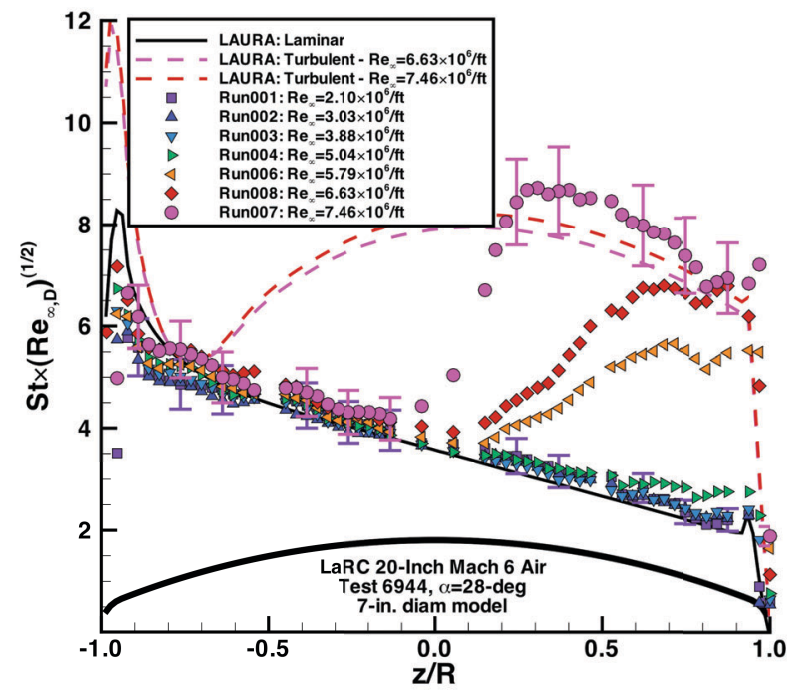

Mach 6, 7-inch diameter model, $\alpha=28$-deg

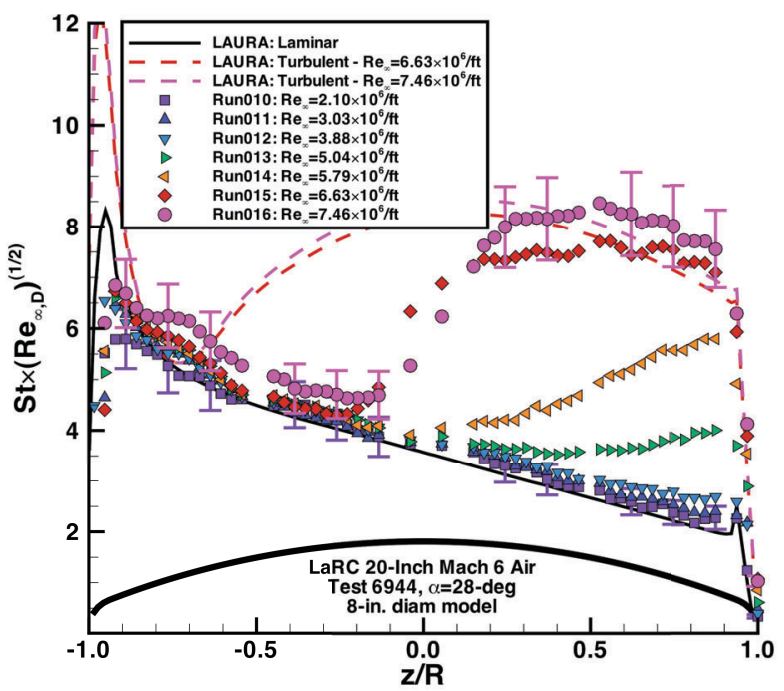

Mach 6, 8-inch diameter model, $\alpha=28$-deg

Figure 15. CEV $\alpha=28-d e g$ Data and Comparisons from LaRC 20-Inch Mach 6 Air Test 6944

\section{Comparison and Correlation of Heating Data Sets}

Having presented an overview of the various experimental turbulent aeroheating data sets available on blunt bodies in the previous section, facility-to-facility correlations of the data will now be demonstrated. Such correlations can provide a valuable check on experimental methods employed in each test and the resulting data. 
In the heating plots shown previously herein, the data have been presented in terms of a correlation parameter based on free stream conditions:

(1) $S t \times \sqrt{\operatorname{Re}_{\infty, D}} \equiv\left[\frac{\dot{q}_{w}}{\rho_{\infty} U_{\infty}\left(H_{0}-H_{w}\right)}\right] \sqrt{\frac{\rho_{\infty} U_{\infty} D}{\mu_{\infty}}}$

As has been shown in these plots, this parameter correlates the Reynolds number dependence of the laminar heating distributions to a separate, nearly-constant curve for each facility at a given angle-of-attack. However, close examination of these figure reveals that the correlation is facility-dependent, as shown in Figure 16. The reason that these correlations are not universal is that the laminar heating rates have Mach number compressibility and enthalpy ratio dependencies and these parameters vary from facility to facility. However, a universal form of the correlation can be determined by reference to the original boundary-layer based heat-transfer correlation form.

The $S t \times\left(\mathrm{Re}_{s, \mathrm{D}}\right)^{0.5}$ factor can be derived from boundary-layer correlations for stagnation point heating, such as those by Fay and Riddell or Van Driest (e. g. Ref. 23). Since the data in question are all from low-enthalpy, perfectgas test conditions, the Van Driest formulation can be employed for simplicity:

(2) $\dot{q}_{w}=0.763 \operatorname{Pr}^{-0.6}\left(\rho_{e} \mu_{e}\right)^{0.5} \sqrt{\frac{d U_{e}}{d x}}\left(H_{a w}-H_{w}\right)$

With some algebraic re-arrangement and the use of the Euler / Newtonian approximations for the velocity gradient term, Eq. (1) becomes

$$
S t_{e} \times \sqrt{\operatorname{Re}_{e, R_{N}}}=\left[\frac{\dot{q}_{w}}{\rho_{e} U_{e}\left(H_{a w}-H_{w}\right)}\right] \sqrt{\frac{\rho_{e} U_{e} R_{N}}{\mu_{e}}}=0.763 \operatorname{Pr}^{-0.6}\left(2 \frac{\rho_{\infty}}{\rho_{e}}\right)^{1 / 4} \sqrt{\frac{U_{\infty}}{U_{e}}}
$$

where the Stanton and Reynolds numbers are defined in terms of boundary-layer edge conditions, not free stream conditions. With further algebra, this equation can be re-formulated in terms of free stream conditions as:

(4) $S t \times \sqrt{\operatorname{Re}_{\infty, R_{N}}}=0.907 \operatorname{Pr}^{-0.6} \sqrt{\frac{\rho_{e} \mu_{e}}{\rho_{\infty} \mu_{\infty}}}\left(\frac{H_{a w}-H_{w}}{H_{0}-H_{w}}\right)\left(\frac{\rho_{\infty}}{\rho_{e}}\right)^{1 / 4}$

For perfect-gas, stagnation point conditions, the assumptions can be made that $\operatorname{Pr}=$ constant and $H_{\mathrm{aw}}=H_{0}$. Thus:

(5) $\left(S t \times \sqrt{\operatorname{Re}_{\infty, R_{N}}}\right)\left[\sqrt{\frac{\rho_{\infty} \mu_{\infty}}{\rho_{e} \mu_{e}}}\left(\frac{\rho_{e}}{\rho_{\infty}}\right)^{1 / 4}\right]=0.907 \operatorname{Pr}^{-0.6}$

Now define a laminar correlation factor as

$$
\beta_{L} \equiv\left[\sqrt{\frac{\rho_{\infty} \mu_{\infty}}{\rho_{e} \mu_{e}}}\left(\frac{\rho_{e}}{\rho_{\infty}}\right)^{1 / 4}\right]
$$

For a hemisphere, $\mathrm{R}_{\mathrm{n}}=\mathrm{D} / 2$, but for spherical arc-segment (e.g. CEV) or sphere-cone (e.g. MSL) an effective nose radius is employed in place of a hemispherical nose radius, where:

(7) $R_{N, \text { eff }}=D \times \mathrm{C}_{\text {shape-factor }}$; where $\mathrm{C}_{\text {shape-factor }}$ is a geometry - and angle of attack - dependent constant

Then finally

(8) $\left[S t \times \sqrt{\operatorname{Re}_{\infty, D}}\right] \beta_{L}=$ local constant $=\mathrm{f}($ geometry,$\alpha)$

It should also be noted that the original 0.763 leading constant in Eq. (2) is actually dependent on the atmospheric compositions (e.q. Ref. 24). However, for the perfect-gas Air and $\mathrm{N}_{2}$ of these data sets, that constant differs by less than $1 \%$.

While this analysis is derived from a stagnation-point equation, the flow over the entire surface of a blunt body is similar enough to stagnation point flow that Eq. (8) applies anywhere on the body, albeit with different values for the local constant. That local constant could, if explicitly desired, be determined from the wind tunnel data (or estimated by various theoretical methods), but the purpose of this analysis was to determine a formulation by which 
the various data sets could be correlated. And, in contrast to the free stream parameter correlations in Figure 16, the laminar data shown in Figure 17 are well correlated in terms of the edge-condition based definition of Eq. (8). The heating distributions from a wide range of free stream Reynolds numbers in three different facilities (or four facilities if the AEDC Tunnel 9 Mach 8 and Mach 10 nozzles are considered separately) have been collapsed to a single band of data with a spread of about $\pm 15 \%$ (except around the stagnation point, where difference from laminar predictions have been noted in several studies - e.g. Refs. 10, 17).

It should be noted that although these edge-based parameters provide a much better correlation for the MSL and CEV configurations, they are typically not used in standard data-reduction schemes. The free-stream based parameters are simpler to determine and do tend to correlate the data from a single facility. Additionally, the edgebased definitions contain assumptions that apply only to a blunt-body stagnation region and would not be applicable to a flat-plate, small-angle sphere-cone, or complex geometry - see for example the correlation for small-angle biconics in Ref. 25 which includes free-stream Mach number and cone-angle corrections. Thus, to avoid ambiguity, data from wind tunnel are typically defined in terms of free stream conditions such as shown in Figure 3 - Figure 15.

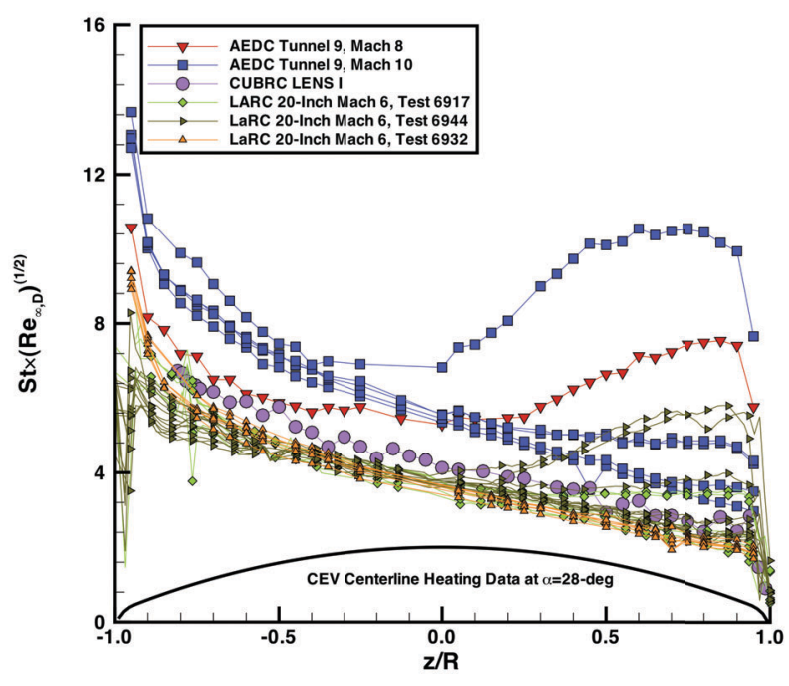

CEV $\alpha=28$-deg data

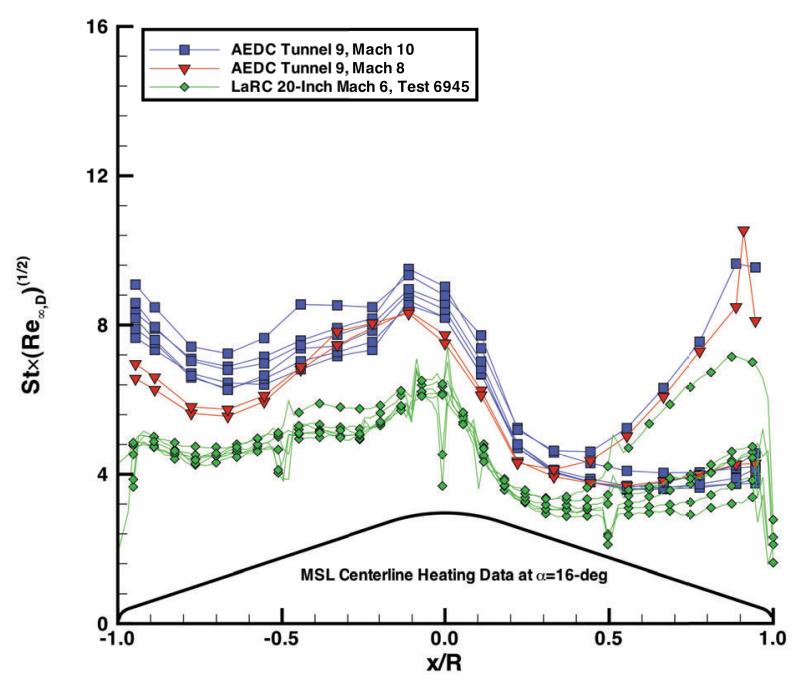

MSL $\alpha=16$-deg data

Figure 16. Failure of Free Stream Parameters to Correlate Laminar Data from Different Facilities

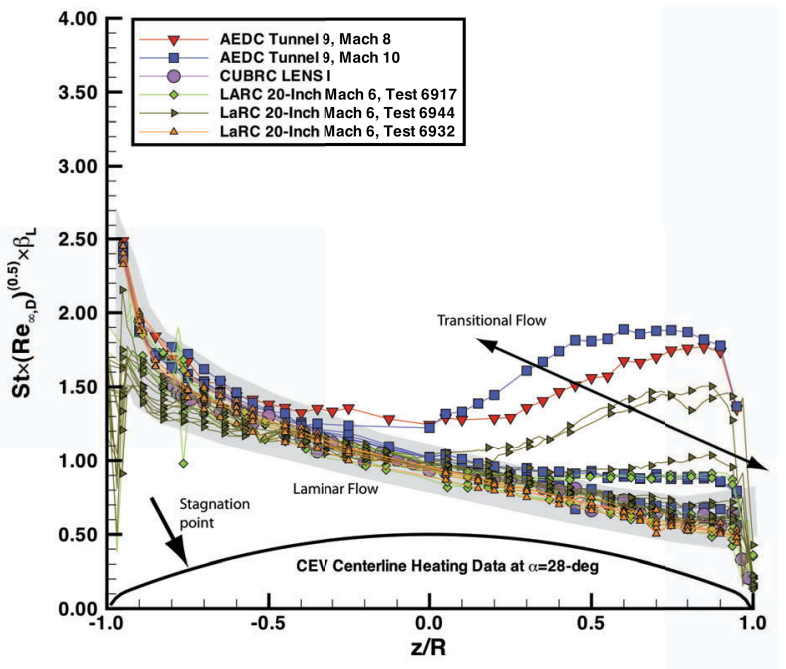

CEV $\alpha=28$-deg data

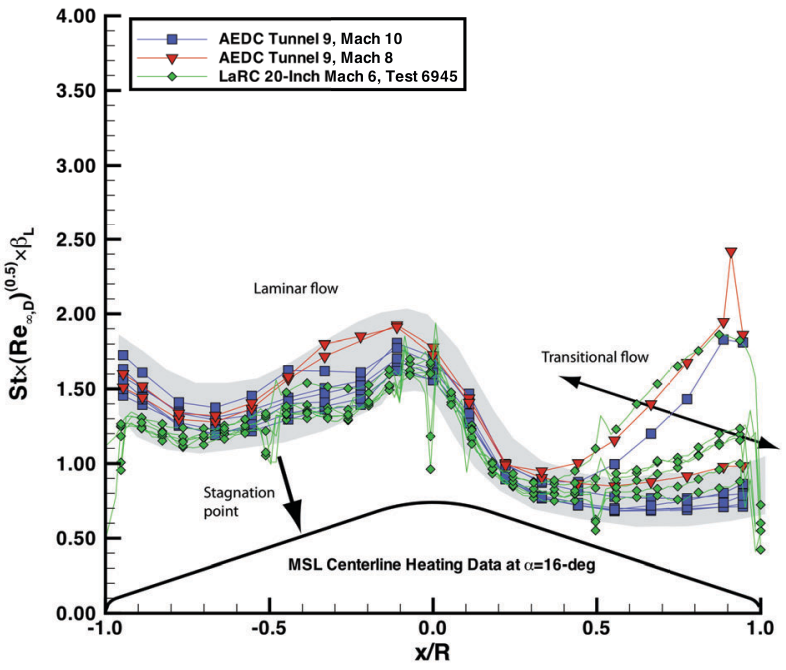

MSL $\alpha=16$-deg data

Figure 17. Correlation of Laminar Data Using Corrected Parameters 
While the edge-based definitions can be used to correlate laminar data, they fail when applied to the turbulent data as is shown in Figure 18.
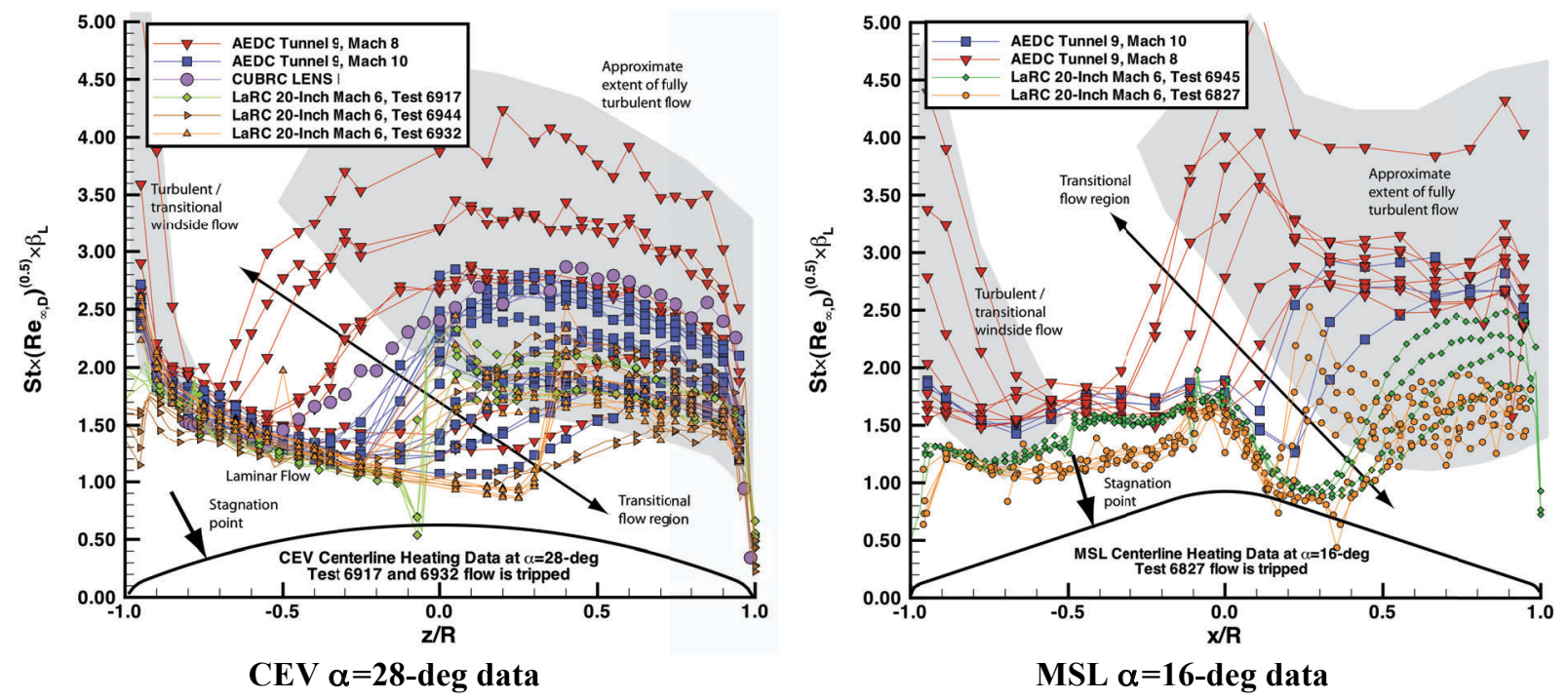

Figure 18. Failure of Corrected Laminar Parameters to Correlate Turbulent Data

This result is to be expected as the original stagnation-point correlation does not include the effects of turbulence. Employing an analogy to incompressible boundary-layer flow over a flat-plate, the laminar and turbulent skin friction coefficients (and by Reynolds analogy, the heat-transfer coefficients) have the forms:

(9) $c_{f, \text { laminar }} \propto \frac{1}{\left(\operatorname{Re}_{\infty, x}\right)^{0.5}}$

(10) $c_{f, \text { turbulent }} \propto \frac{1}{\left(\operatorname{Re}_{\infty, x}\right)^{0.2}}$

Based on this relations, it could be hypothesized that a turbulent correlation function analogous to the laminar correlation function would be given by:

(11) $S t \times\left(\operatorname{Re}_{\infty, D}\right)^{0.2}\left[\left(\frac{\rho_{\infty} \mu_{\infty}}{\rho_{e} \mu_{e}}\right)^{0.2}\left(\frac{\rho_{e}}{\rho_{\infty}}\right)^{1 / 4}\right] \approx$ constant

Unfortunately, evaluation of the data sets in terms of these parameters did not result in a valid correlation of the turbulent data. Instead, through trial-and-error empiricism, it was found that the turbulent data could be correlated with slightly different exponents:

$S t \times\left(\operatorname{Re}_{\infty, D}\right)^{0.17}\left[\left(\frac{\rho_{\infty} \mu_{\infty}}{\rho_{e} \mu_{e}}\right)^{1 / 3}\left(\frac{\rho_{e}}{\rho_{\infty}}\right)^{1 / 4}\right]=\left[S t \times\left(\operatorname{Re}_{\infty, D}\right)^{0.17}\right] \beta_{\mathrm{T}}=$ local constant $=\mathrm{f}($ geometry,$\alpha)$

where

(13) $\beta_{T}=\left(\frac{\rho_{\infty} \mu_{\infty}}{\rho_{e} \mu_{e}}\right)^{1 / 3}\left(\frac{\rho_{e}}{\rho_{\infty}}\right)^{1 / 4}$ 
This formulation was applied to all the turbulent CEV and MSL from all tests. As shown in Figure 19 and Figure 20, the turbulent data for each angle-of-attack correlated to within $\sim \pm 15 \%$, including both the natural and tripped transition cases. Correlation formulations have thus been validated for data from multiple facilities and test conditions for laminar heating - as given by Eq. (8) - and for turbulent heating - as given by Eq. (12).

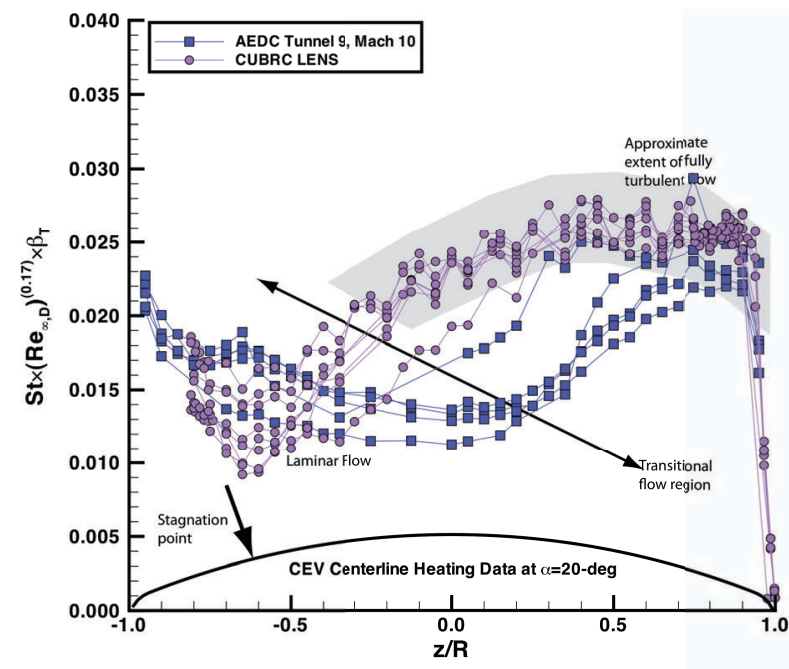

CEV $\alpha=20-$ deg data

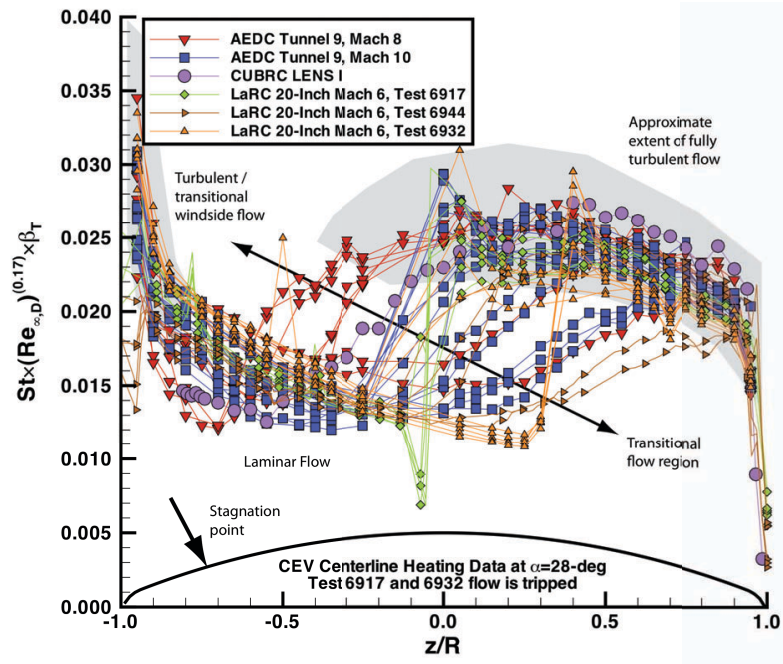

CEV $\alpha=28-d e g$ data

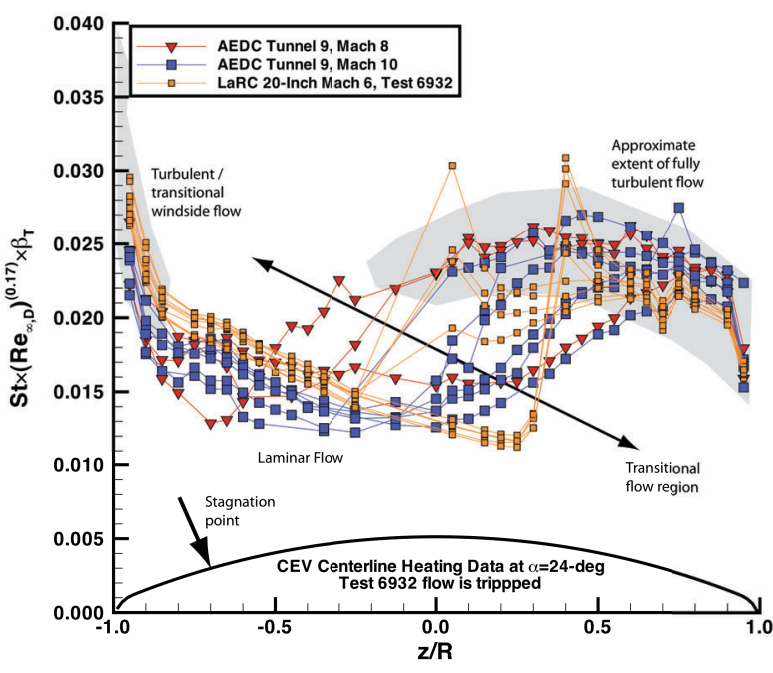

CEV $\alpha=24-d e g$

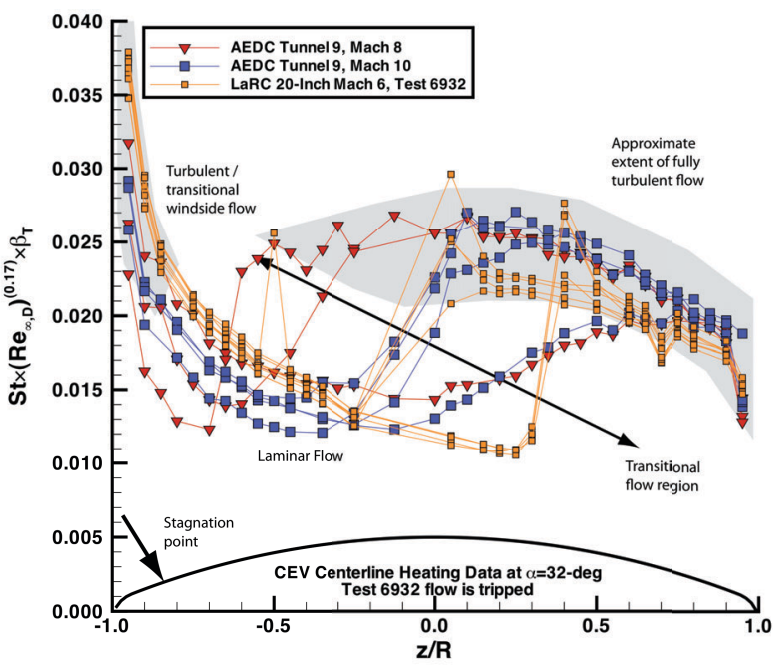

CEV $\alpha=32-\operatorname{deg}$ data

Figure 19. Correlation of CEV Turbulent Heating Data Using Corrected Turbulent Parameters 

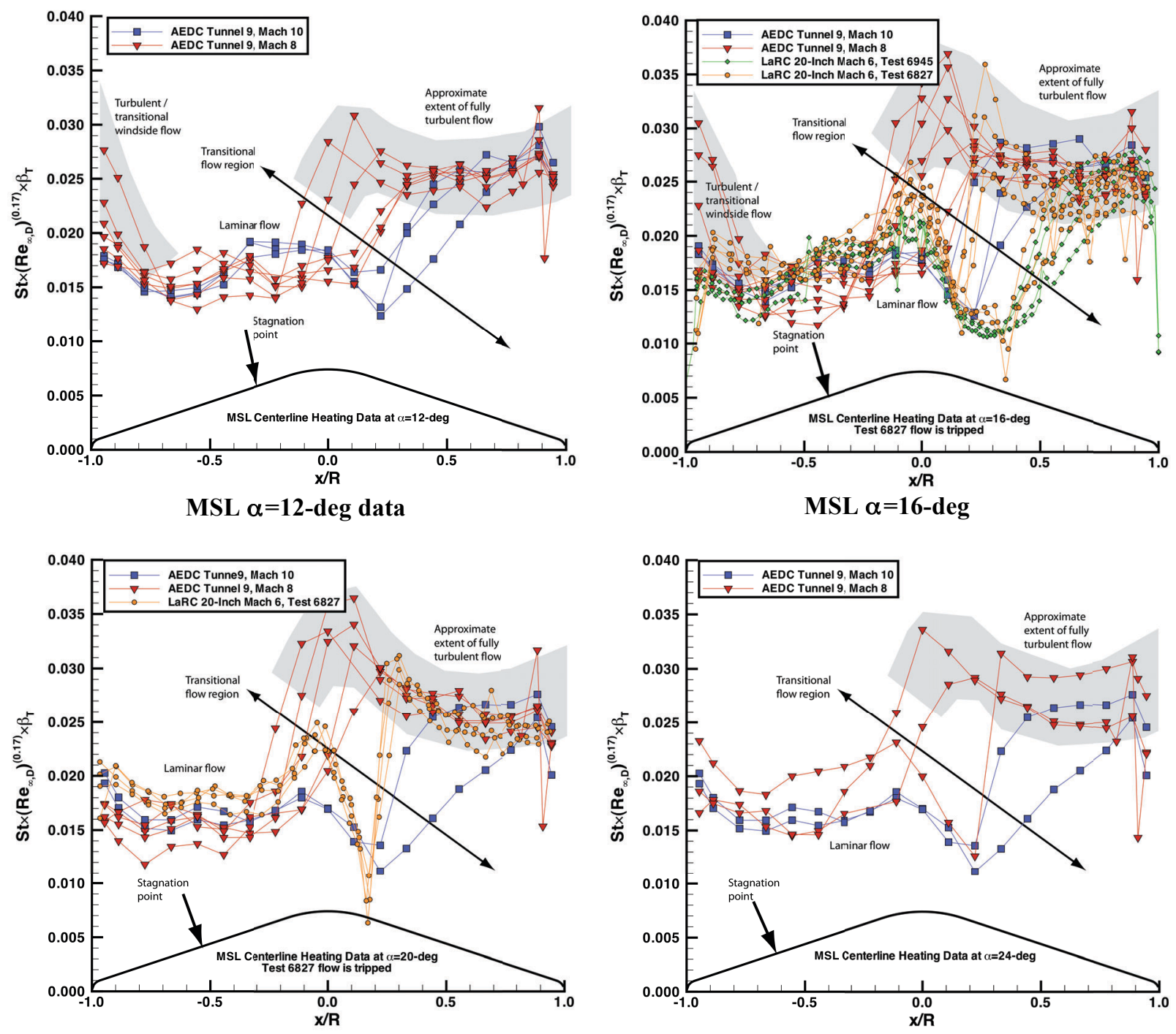

MSL $\alpha=20-$ deg data

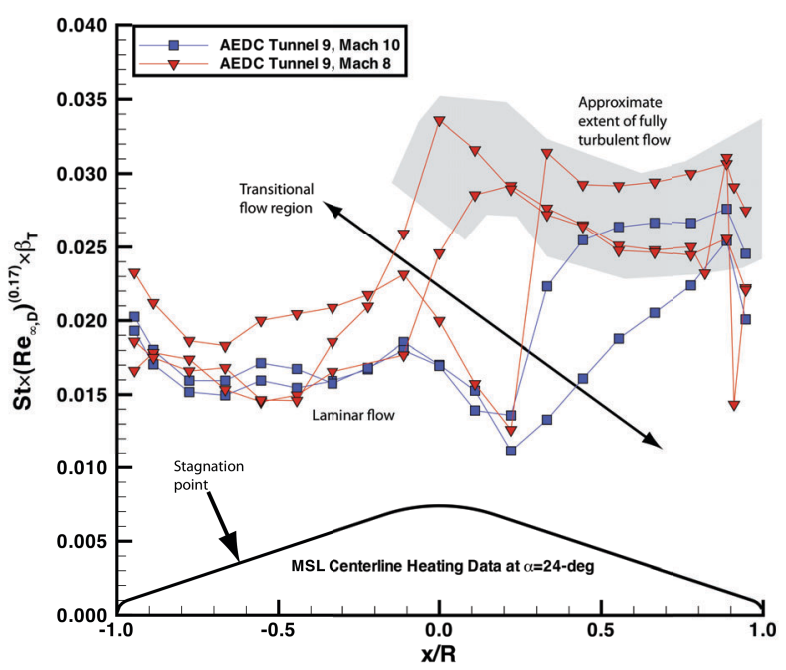

MSL $\alpha=24-d e g$ data

Figure 20. Correlation of MSL Turbulent Heating Data Using Corrected Turbulent Parameters

\section{Turbulent Heating Augmentation and Transition Onset Correlations}

For configuration analysis and design trade studies, it is useful to have engineering-level approximation for the onset of boundary-layer transition and the for resulting turbulent augmentation above laminar levels. While transition is vastly-complex process, engineering literature provides numerous examples of configuration and condition dependent transition correlations of reasonable accuracy. In that spirit, correlations were sought for the MSL and CEV configurations with the limiting assumptions that bound the data sets considered: low-enthalpy, perfect-gas air or $\mathrm{N}_{2}$ flows; cold-wall conditions; subsonic boundary-layer edge conditions; minimal surface roughness; no blowing or ablation; and minimal cross-flow effects.

The response function considered in the generation of these correlations was the ratio of the measured Stanton number to the predicted, cold-wall laminar value.

$$
\phi=\frac{S t_{\text {measured }}}{S t_{\text {predicted,laminar }}}
$$


A predicted value for the dominator was chosen to provide a consistent definition and avoid any statistical fluctuations in the measurements that could bias the results. Based on the comparisons shown herein and the listed references, it was found that the agreement between predicted and measured laminar heating levels for the CEV and MSL geometries was within less than $\pm 10 \%$ and thus the predictions were suitable for use in correlations

With respect to the experimental data employed in the numerator, it is emphasized that the domain of the data set includes all angle-of-attack and all Reynolds numbers from all facilities, the only exception being the tripped boundary-layer data. Furthermore the heating data were considered for the entire forebody (not just along the centerline) up to the rapid flow-expansion point ahead of the vehicle shoulder. A very large data set was thus considered since the AEDC thermocouple models included 38 off-centerline gages for the CEV geometry and 12 off-centerline gages for the MSL geometry and the global thermographic phosphor data sets from the LaRC 20-Inch Mach 6 Air tunnel tests contain $512 \times 480$ pixel arrays.

Following commonly employed practice for transition and heating correlations, the boundary-layer parameters $\mathrm{Re}_{\mathrm{e}}$ and $\mathrm{Re}_{\mathrm{a}} / \mathrm{M}_{\mathrm{e}}$ were considered as forcing functions. These values were extracted from the predicted flow fields using a boundary-layer edge location definition as the point where the local enthalpy is 0.995 of the free stream total enthalpy.

The resulting correlations for MSL and CEV in terms of $\mathrm{Re}_{a} / \mathrm{M}_{\mathrm{e}}$ are presented in Figure 21. Given that these flow fields all have subsonic to barely supersonic $\left(M_{e}<1.5\right)$ edge conditions, this method was not expected to produce good results. And, in fact, the CEV data were completely uncorrelated in terms of $R_{e} / M_{e}$. The MSL results did though provide a reasonable correlation: transition onset occurs between $300<\mathrm{Re}_{\triangleleft} / \mathrm{M}_{\mathrm{e}}<600$ and the augmentation factor asymptotes to a linear relationship with $\mathrm{Re}_{\mathrm{e}} / \mathrm{M}_{\mathrm{e}}$.

As shown in Figure 22, the correlations in terms of $\mathrm{Re}_{\text {. }} \mathrm{vs.} \phi$ were considerably better than those in terms of $\mathrm{Re}_{\triangleleft} / \mathrm{M}_{\mathrm{e}} \mathrm{vs} \phi$. Transition onset for the CEV geometry is clearly defined at around $\mathrm{Re}_{\mathrm{v}}=200$, although a slight inverse relationship between free stream Reynolds number and transition $\mathrm{Re}_{\text {。 }}$ was observed. Whether this is a truly flightrelevant relationship or a function of increasing free stream noise levels with Reynolds number in the wind tunnel testing is unclear. For the MSL geometry, a slightly less defined $\mathrm{Re}_{\text {e }}$ transition onset was observed (although considerably better defined that for $\mathrm{Re}_{\mathrm{v}} / \mathrm{M}$ ) with values between $\mathrm{Re}_{\mathrm{e}}=200$ to 300. A similar inverse relationship was observed between free stream Reynolds number and transition onset $\mathrm{Re}_{\text {. }}$.

The complete failure of the $\mathrm{Re}_{\mathrm{e}} / \mathrm{M}_{\mathrm{e}}$ formulation for the CEV dataset but not for the MSL dataset can be explained by the relative complexity of the surface geometries and resulting flow fields. The CEV is a simple spherical-cap segment, whereas the MSL is a sphere-cone. Samples of the resulting $R e_{e} / M_{e}$ and $R_{e}$ distributions produced over

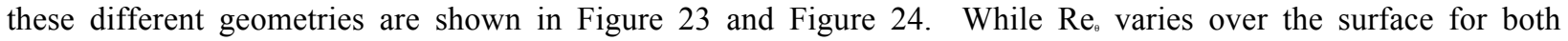
geometries, $\mathrm{Re}_{\mathrm{e}} / \mathrm{M}_{\mathrm{e}}$ is very nearly constant over the CEV geometry; thus it cannot be used as a correlation parameter for the CEV.

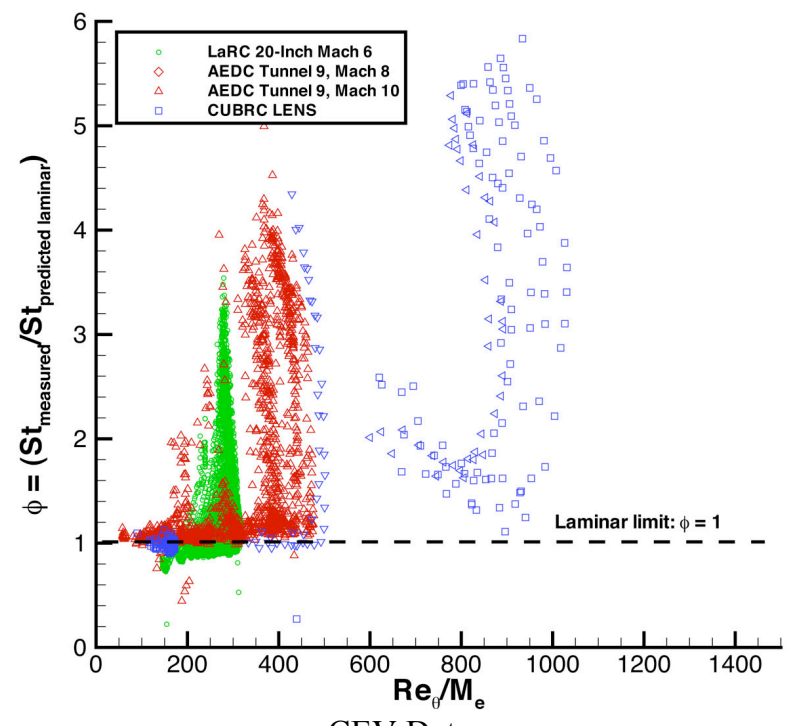

CEV Data

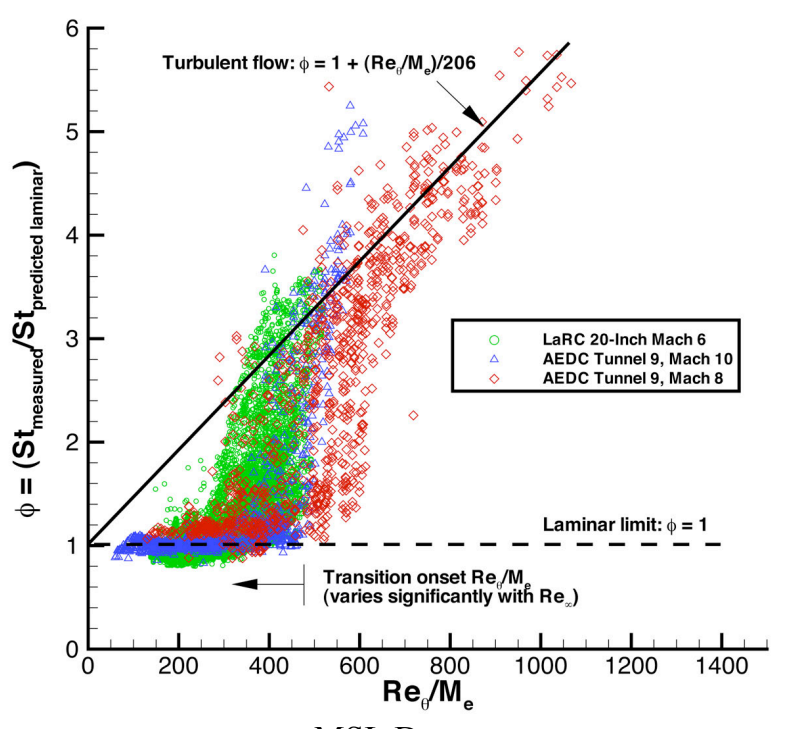

MSL Data

Figure 21. Correlation of Turbulent Heating Augmentation Factor in Terms of $R_{e} / M_{e}$ 


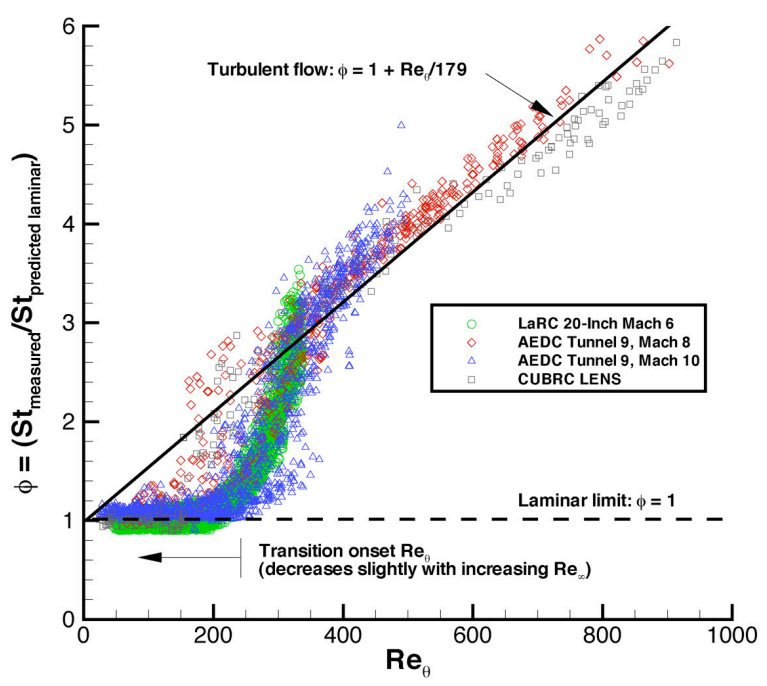

CEV Data

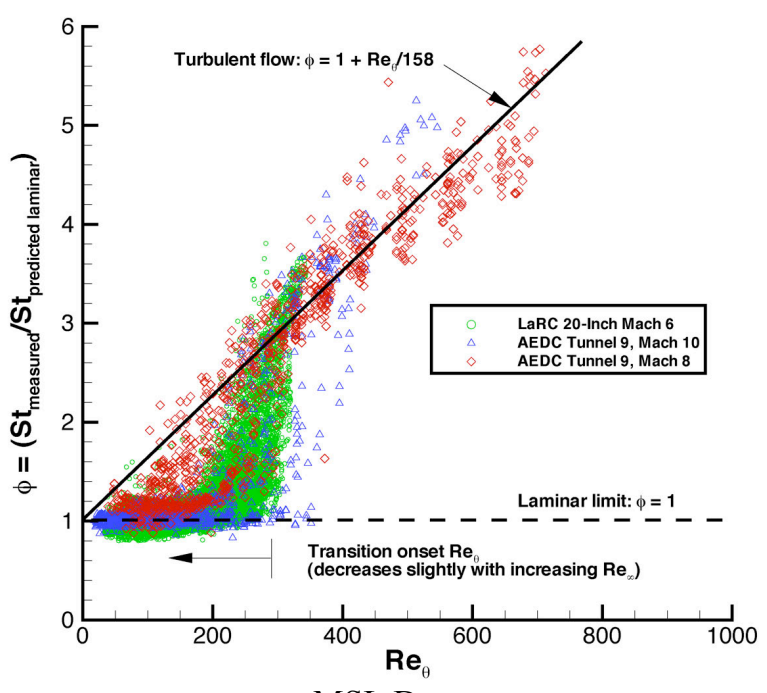

MSL Data

Figure 22. Correlation of Turbulent Heating Augmentation Factor in Terms of Re。

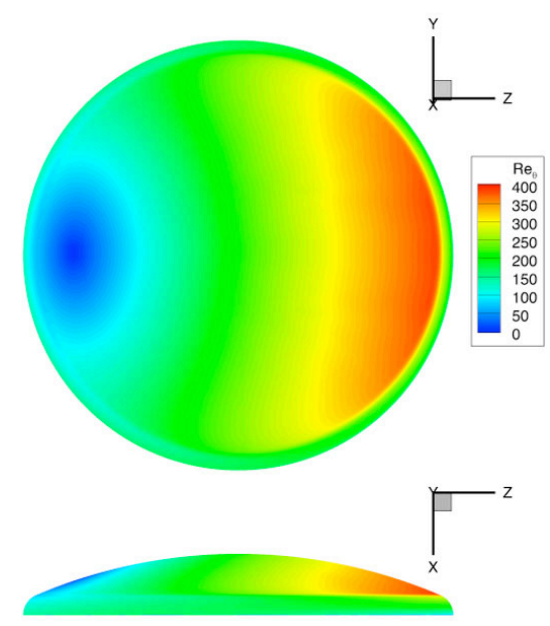

$\mathrm{CEV}, \alpha=28-\mathrm{deg}$
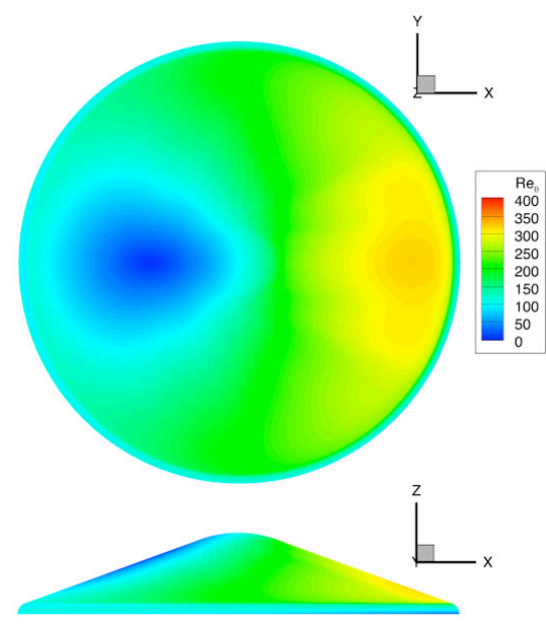

MSL, $\alpha=16-$ deg

Figure 23. Sample $\mathrm{Re}_{\text {。 }}$ distributions for CEV and MSL, Mach 6, Re $=7.5 \times 10^{6} / \mathrm{ft}$

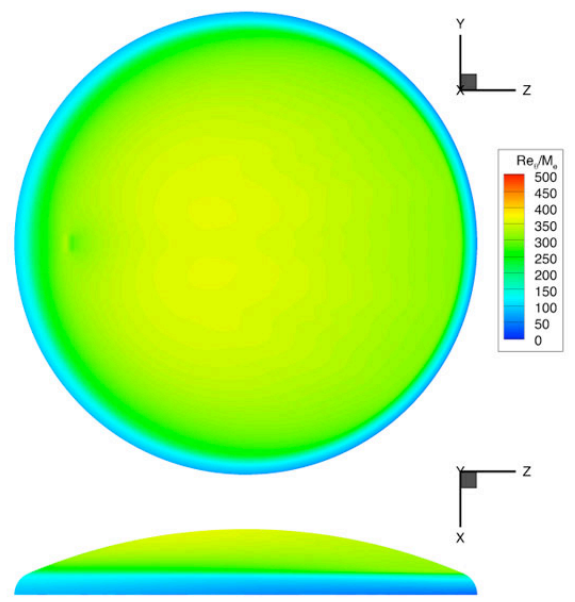

CEV, $\alpha=28-$ deg
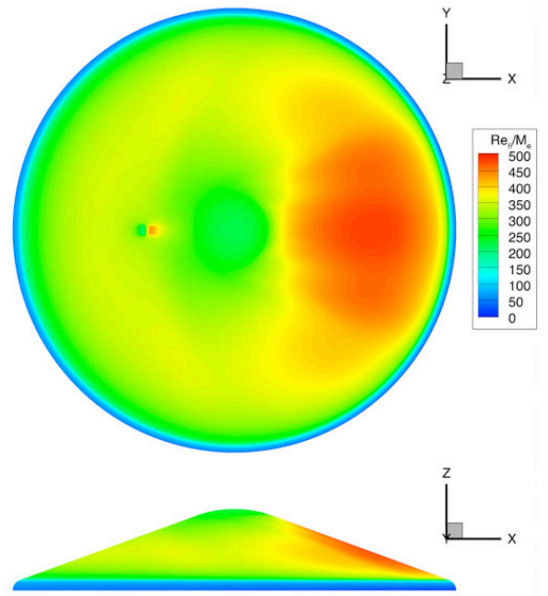

MSL, $\alpha=16-\operatorname{deg}$

Figure 24. Sample $R_{e} / M_{e}$ distributions for CEV and MSL, Mach 6, Re $e_{s}=7.5 \times 10^{6} / \mathrm{ft}$ 
With respect to transition, these results tend to confirm commonly-employed "rule-of-thumb" assumptions that transition on smooth blunt bodies occurs for an $\mathrm{Re}_{\mathrm{e}}$ of approximately 200 . With respect to heating, the correlations show that for both CEV and MSL, the turbulent heating augmentation factors asymptote to linear functions of $\mathrm{Re}_{\text {}}$ and $\phi$ given by:

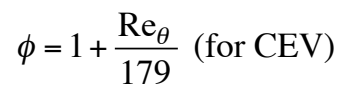

and

(16) $\phi=1+\frac{\operatorname{Re}_{\theta}}{158}$ (for MSL)

These two functions are similar enough that to suggest that for subsonic flow, there may be a universal correlation function for blunt-body turbulent heating augmentation. However, more data would be required on other blunt-body geometries to validate such an assumption.

\section{Summary and Recommendations}

An overview of recent turbulent aeroheating studies on the CEV and MSL blunt body geometries has been presented. Sample data and comparisons have been presented for each test. From these data, edge-based parameters have been validated for the correlation of both laminar and turbulent heating data from multiple facilities and test conditions. These parameters are:

For laminar flow:

$$
\left[S t \times\left(\operatorname{Re}_{\infty, D}\right)^{1 / 2}\right] \times \beta_{L}=S t \times\left(\operatorname{Re}_{\infty, D}\right)^{1 / 2}\left[\left(\frac{\rho_{\infty} \mu_{\infty}}{\rho_{e} \mu_{e}}\right)^{1 / 2}\left(\frac{\rho_{e}}{\rho_{\infty}}\right)^{1 / 4}\right]=\text { local constant }=\mathrm{f}(\text { geometry }, \alpha)
$$

For turbulent flow:

$$
\left[S t \times\left(\operatorname{Re}_{\infty, D}\right)^{0.17}\right] \times \beta_{\mathrm{T}}=S t \times\left(\operatorname{Re}_{\infty, D}\right)^{0.17}\left[\left(\frac{\rho_{\infty} \mu_{\infty}}{\rho_{e} \mu_{e}}\right)^{1 / 3}\left(\frac{\rho_{e}}{\rho_{\infty}}\right)^{1 / 4}\right]=\text { local constant }=\mathrm{f}(\text { geometry }, \alpha)
$$

Transition onset and turbulent heating augmentation factors were also determined from these data and correlated with the boundary-layer momentum thickness Reynolds number, $\mathrm{Re}_{\bullet}$. For the CEV and MSL geometries, it was found that transition onset was given by:

$$
\operatorname{Re}_{\theta} \approx 200 \text { to } 300
$$

and the turbulent heating augmentation factors asymptotically approached limits given by:

(20) $\phi=1+\frac{\operatorname{Re}_{\theta}}{179}$ (for CEV)

(21) $\phi=1+\frac{\operatorname{Re}_{\theta}}{158}$ (for MSL)

The relationships for laminar and turbulent heating and boundary-layer transition onset given by Eqs. (17) - (21) provide engineering-level design methods that can be employed in configuration design, development and optimization studies of blunt-body entry vehicles.

These functions have been shown to be provide good representations of the data from which they were derived; however, significant gaps in the extent of the data can be inferred from consideration of the test conditions. Specifically, the experimental data sets do not encompass the effects on transition and heating of: high-enthalpy chemistry (total enthalpy levels $>>1 \mathrm{MJ} / \mathrm{kg}$ ); "hot" walls $\left(\mathrm{T}_{\mathrm{w}}>>300 \mathrm{~K}\right)$; test-gas effects (e.g. $\mathrm{CO}_{2}$ for Mars); or surface roughness and blowing (due to ablation). These effects have not been considered because, for blunt bodies such as CEV and MSL, there are very few experimental data sets available in which these phenomena are present. It is thus recommended that acquisition of such data should be a priority in future research. 


\section{References}

${ }^{1}$ Davies, C., "Planetary Mission Entry Vehicles Quick Reference Guide, Version 3.0," NASA SP-2006-3401, 2006.

${ }^{2}$ Prakash, R., et al, "Mars Science Laboratory Entry, Descent, and Landing System Overview," IEEE Paper 2008-1531, IEEE Aerospace Conference, Big Sky, MT, March 1-8, 2008.

${ }^{3}$ Edquist, K. T., Dyakonov, A. A., Wright, M. J., and Tang, C. Y., "Aerothermodynamic Design of the Mars Science Laboratory Heatshield," AIAA Paper 2009-4075, 41st AIAA Thermophysics Conference, San Antonio, TX, June 22-25, 2009.

${ }^{4}$ Wright, M. J. Beck, R. A. S, Edquist, K. T., et al, "Sizing and Margins Assessment of the Mars Science Laboratory Aeroshell Thermal Protection System," AIAA Paper 2009-4231, 41st AIAA Thermophysics Conference, San Antonio, TX, June 22-25, 2009.

${ }^{5}$ Anon., "NASA's Exploration Systems Architecture Study, Final Report,” NASA TM-2005-214062, November 2005.

${ }^{6}$ Greathouse, J. S., Kirk, B. S., Lillard, R. P., Troung, T. H., Robinson, P. and Cerimele, C. J., "Crew Exploration Vehicle (CEV) Crew Module Shape Selection and CEV Aeroscience Project Overview," AIAA Paper 2007-0603, 45 ${ }^{\text {th }}$ AIAA Aerospace Sciences Meeting and Exhibit, Reno, NV, January 8 - 11, 2007.

${ }^{7}$ Berry, S. A. and Horvath, T. J., Lillard, R. P., Kirk, B. S., and Cassady, A. M., "Aerothermal Testing for Project Orion Crew Exploration Vehicle," AIAA Paper 2009-3842, 41st AIAA Thermophysics Conference, San Antonio, TX, June 22-25, 2009.

${ }^{8}$ Micol, J. R. "Langley Aerothermodynamic Facilities Complex: Enhancements and Testing Capabilities," AIAA Paper 98-0147, $36^{\text {th }}$ Aerospace Sciences Meeting and Exhibit, Reno, NV, January 12-15, 1998.

${ }^{9}$ Marren, D., and Lafferty, J., "The AEDC Hypervelocity Wind Tunnel 9," Advanced Hypersonic Test Facilities, Progress in Aeronautics and Astronautics, Vol. 198, American Institute of Aeronautics and Astronautics, Reston, VA, 2002, pp. 467-477.

${ }^{10}$ Holden, M. S., Wadhams, T. P., and Candler, G. V., "Experimental Studies in the LENS Shock Tunnel and Expansion Tunnel to Examine Real-Gas Effects in Hypervelocity Flows," AIAA Paper 2004-0916, January 2004.

${ }^{11}$ Hollis, B. R. and Collier, B. R., "Turbulent Aeroheating Testing of Mars Science Laboratory Entry Vehicle," Journal of Spacecraft and Rockets, Vol. 45, No. 3, May-June-2008, pp. 417-427.

${ }^{12}$ Liechty, D. S. and Hollis, B. R., and, "Mars Science Laboratory Experimental Aerothermodynamics with Effects of Cavities and Control Surfaces," Journal of Spacecraft and Rockets, Vol. 43, No. 2, March-April 2006, pp. 340-353.

${ }^{13}$ Hollis, B. R. and Liechty, D. S., "Transition Due to Heat-Shield Cavities on a Mars Entry Vehicle," Journal of Spacecraft and Rockets, Vol. 43, No. 2, March-April 2006, pp. 354-366.

${ }^{14}$ Hollis, B. R. and Liechty, D. S., "Correlations for Boundary-Layer Transition on Mars Science Laboratory Entry Vehicle Due to Heat-Shield Cavities," NASA TP-2008-215317, June 2008.

${ }^{15}$ Hollis, B. R., Liechty, D. S., Wright, M. J., Holden, M. S., Wadhams, T. P., and MacLean, M., "Transition Onset and Turbulent Heating Measurements for the Mars Science Laboratory Entry Vehicle," AIAA Paper 2005-1437, 43rd AIAA Aerospace Sciences Meeting and Exhibit, Reno NV, January 10-13, 2005.

${ }^{16}$ Hollis, B. R., Berger, K. T., Horvath, T. J., Coblish, J. J., Norris, J. D., Lillard, R. P. and Kirk, B. S., "Aeroheating Testing and Predictions for Project Orion Crew Exploration Vehicle,” Journal of Spacecraft and Rockets, Vol. 46, No. 4, July-August 2009, pp.766-780.

${ }^{17}$ Hollis, B. R., Berger, K. T., Horvath, T. J., Lillard, R. P. and Kirk, B. S., Coblish, J. J., Norris, J. D., "Experimental Investigation of Project Orion Crew Exploration Vehicle Aeroheating in AEDC Tunnel 9," NASA TP-2008-215547, December, 2008.

${ }^{18}$ Wadhams, T. P., Cassady, A. M., MacLean, M., and Holden, M. S., "Experimental Studies of the Aerothermal Characteristics of the Project Orion CEV Heat Shield in High Speed Transitional and Turbulent Flows," AIAA Paper 2009-0677, 47th AIAA Aerospace Sciences Meeting, Orlando, FL, January 5-8, 2009.

${ }^{19}$ Berger, K. T., "Aerothermodynamic Testing of the Crew Exploration Vehicle at Mach 6 and Mach 10," Journal of Spacecraft and Rockets, Vol. 46, No. 4, July-August 2009, pp.758-765.

${ }^{20}$ Hollis, B. R., "Experimental Investigation of Project Orion Crew Exploration Vehicle Aeroheating: LaRC 20-Inch Mach 6 Air Tunnel Test 6931," NASA TM-2009-215718, April 2009.

${ }^{21}$ Amar, A. J., Horvath T. J., Hollis, B. R., Berger, K. T., Berry, S. A., and Calvert, N., "Protuberance Boundary Layer Transition for Project Orion Crew Entry Vehicle," AIAA Paper 2008-1227, 46th AIAA Aerospace Sciences Meeting and Exhibit, Reno, NV, January 7-10, 2008.

${ }^{22}$ Cheatwood, F. M., and Gnoffo, P. A., "User's Manual for the Langley Aerothermodynamic Upwind Relaxation Algorithm (LAURA)," NASA TM 4674, April, 1996.

${ }^{23}$ Anderson, J. D., Hypersonic and High Temperature Gas Dynamics, American Institute of Aeronautics and Astronautics, Reston, VA, 2000.

${ }^{24}$ Sutton, K., and Graves, R. A., “A General Stagnation-Point Convective-Heating Equation for Arbitrary Gas Mixtures,” NASA TR-R 376, November 1971.

${ }^{25}$ Miller, C. G., Micol, J. R., and Gnoffo, P. A., "Laminar Heat-Transfer Distributions on Biconics at Incidence in Hypersonic, Hypervelocity Flows,” NASA TP-2213, January, 1985. 